\title{
A review of the fisheries, life history and stock structure of tropical tuna (skipjack Katsuwonus pelamis, yellowfin Thunnus albacares and bigeye Thunnus obesus) in the Indian Ocean
}

\author{
Artetxe-Arrate Iraide ${ }^{1,}{ }^{*}$, Fraile Igaratza ${ }^{1}$, Marsac Francis ${ }^{2,3}$, Farley Jessica $\mathrm{H}^{4}$, \\ Rodriguez-Ezpeleta Naiara ${ }^{1}$, Davies Campbell R ${ }^{4}$, Clear Naomi P ${ }^{4}$, Grewe Peter ${ }^{4}$, Murua Hilario ${ }^{1,5}$
}

${ }^{1}$ AZTI, Marine Research, Basque Research and Technology Alliance (BRTA), Herrea Kaia, Pasaia, Gipuzkoa, Spain

2 MARBEC, Univ Montpellier, CNRS, Ifremer, IRD, Sète, France

${ }^{3}$ Institut de Recherche pour le Développement (IRD), Sète, France

${ }^{4}$ CSIRO Oceans and Atmosphere, Castray Esplanade, Hobart, TAS, Australia

5 International Seafood Sustainability Foundation, Washington, DC, United States

* Corresponding author : Iraide Artetxe-Arrate, email address : i.artetxe73@gmail.com

\begin{abstract}
:
Skipjack (Katsuwonus pelamis), yellowfin (Thunnus albacares) and bigeye (Thunnus obesus) tuna are the target species of tropical tuna fisheries in the Indian Ocean, with high commercial value in the international market. High fishing pressure over the past three decades has raised concerns about their sustainability. Understanding life history strategies and stock structure is essential to determine species resilience and how they might respond to exploitation. Here we provide a comprehensive review of available knowledge on the biology, ecology, and stock structure of tropical tuna species in the Indian Ocean. We describe the characteristics of Indian Ocean tropical tuna fisheries and synthesize skipjack, yellowfin, and bigeye tuna key life history attributes such as biogeography, trophic ecology, growth, and reproductive biology. In addition, we evaluate the available literature about their stock structure using different approaches such as analysis of fisheries data, genetic markers, otolith microchemistry and tagging, among others. Based on this review, we conclude that there is a clear lack of ocean basin-scale studies on skipjack, yellowfin and bigeye tuna life history, and that regional stock structure studies indicate that the panmictic population assumption of these stocks should be investigated further. Finally, we identify specific knowledge gaps that should be addressed with priority to ensure a sustainable and effective management of these species.
\end{abstract}

Keywords : Indian Ocean, Tropical tuna, Fisheries, Life history, Stock structure, Tuna biology, Tuna ecology, Skipjack tuna, Yellowfin tuna, Bigeye tuna 
Skipjack (Katsuwonus pelamis), yellowfin (Thunnus albacares) and bigeye (Thunnus obesus) tuna are members of the Scombridae family. They are commonly referred to as tropical tuna because they inhabit tropical and subtropical waters of the three major oceans (Atlantic, Indian, and Pacific). These species represent a vital source of food, employment and livelihood for numerous coastal communities and nations (FAO, 2016). Two main markets drive tuna production; traditional canned tuna, dominated by light meat and bigeye tuna are preferred (FAO, 2018). Market demand for tuna has increased over the last few decades, which has led to increased exploitation. Global catch of tuna species in 2018 was 5.1 million tonnes, of which tropical tuna species accounted for $95 \%$ (ISSF, 2020). In addition to being a major component of the global fishing industry, tropical tuna are also amongst the world's most valuable fish (Galland et al., 2016), Tropical tuna contribute considerably to the global economy ( $\$ 29.17$ billion market value), and account for the $88.5 \%$ of the global tuna sales value in 2014 (Macfadyen, 2016). The Pacific Ocean supports the world's largest tuna fisheries, followed by the Indian Ocean, which accounts for $21 \%$ of worldwide tropical tuna catches (Galland et al., 2016). Tropical tuna are an important source of food for millions of people around the world, and support the livelihoods and employment of local communities and fishermen who depend on them (FAO, 2016). These species are top predators that play a significant role in the open ocean ecosystems, due to their influence in marine food webs structure and dynamics (Estes et al., 2016; van Denderen et al., 2018), hence their decline can initiate trophic cascades (Heithaus et al., 2008), and jeopardise the resilience and stability of marine resources (Kerr et al., 2016).

Despite their inherent importance to the marine ecosystem, the global economy and human wellbeing, the complex and diverse range of countries participating in tuna Regional Fisheries Management Organizations (tRFMOs), organizations responsible for managing tuna and tuna-like species, hinder the implementation of effective conservation strategies to ensure the sustainability of tuna and related ecosystems (CullisSuzuki and Pauly, 2010; Collette, 2017; Juan-Jordá et al., 2017). This is particularly true in the Indian Ocean, where the co-existence of artisanal and industrial fisheries (total catches are divided about equally 
between them), poses a major challenge for the assessment and management of Indian Ocean tropical tuna stocks by the Indian Ocean Tuna Commission (IOTC) (Murua et al., 2015; McCluney et al., 2019). Overall, data collection is less coordinated and naturally more difficult when it comes to small vessels, and management and enforcement outcomes harder to implement (Pons et al., 2017). Many developing countries experience serious capacity and infrastructure constraints, which can impede adequate data collection and reporting (Ceo et al., 2012). And this is particularly the case of the Indian Ocean, where for many tuna species artisanal fisheries, and in some case semi-industrial, tuna catches are estimated by IOTC using several sources of information (see for more details IOTC, 2019c). The difficulty of monitoring the fisheries within the Indian Ocean not only affects the stock assessment process, but also the implementation of the agreed management measures in the IOTC area. For instance, although catch limitations of yellowfin tuna in the Indian Ocean were agreed due to the overfished status of the stock (IOTC Resolution 19/01), the measure failed to achieve its goal as catches has increased by around $9 \%$ in 2018 from 2014/2015 levels despite limitations (IOTC, 2019b). Similarly, a Harvest Control Rule was agreed in 2016 for skipjack tuna (IOTC Resolution 16/01), but the resultant catch limit for 2018-2020 has been exceeded in 2018 (IOTC, 2019b). As mis-assessment and mis-management of a species can lead to stock depletion (Hutchings, 2000; Pauly et al., 2003), efforts must focus on improving the capacity of monitoring the fishery to collect fishery statistics and statistical methods needed for improved assessment as well as improving the capacity to implement the agreed management measures of the three tropical tuna stocks (i.e., skipjack, yellowfin and bigeye) under the IOTC mandate.

Understanding life history strategies and stock structure is essential in determining how a species might respond to fishing pressure (Jennings et al., 1998; Begg et al., 1999; Juan-Jordá et al., 2013). Life history information such as age and growth, reproduction, maturity and mortality is required to determine population productivity and, hence, resilience to fisheries (King and McFarlane, 2003; Morgan et al., 2009), while the knowledge on habitat utilization and niche exploitation at different life stages can be useful for evaluations of species-specific vulnerability to different fisheries. Besides, the understanding of stock structure helps determine the appropriate units for stock assessment and suitable spatial scale for management (Kerr et al., 2016). Different stocks (i.e. semi-discrete groups of fish with some definable attributes that are of interest to fishery managers sensu Begg and Waldman 1999) may possess specific genetic, physiological or/and behavioral traits, that can influence life history processes (Stepien, 1995). As such, when the stock structure is more complex than recognized, management measures based on a single 
stock assumption can potentially lead to overexploitation and possible collapse of less productive subpopulations, and under-exploitation of more productive populations (Stephenson, 1999; Ying et al., 2011). Each tropical tuna species is considered to form a single stock in the Indian Ocean for management purposes (IOTC, 2017a, 2017b, 2017c) although spatial structure is recognized in current stock assessments, which need to determine relative abundances among regions (Hoyle, 2018; Hoyle and Langley, 2020). Since 2008, Indian Ocean yellowfin tuna assessments used a spatial stratification (Langley et al., 2008; Fu et al., 2018), and so did recent bigeye assessments (Langley, 2016; Fu, 2019). These models consider spatial differences in catches but assume a single-stock recruitment relationship (i.e. a unique spawning population with no reproductively isolated units). However, scientific evidence on how tropical tuna are structured in the Indian Ocean is required to validate the adequacy of the divisions used in this approach and to resolve the single stock hypothesis assumption, as different scenarios may lead to different management strategies and implications (Fig.1)

The aim of this review is to (i) describe the particularities of Indian Ocean tropical tuna fisheries (ii) synthesize the existing information on Indian Ocean skipjack, yellowfin and bigeye tuna life history strategies, (iii) compile the available information on stock structure sourced from studies using a range of different approaches, and (iv) identify major knowledge gaps and highlight future research priorities needed for the implementation of an effective conservation strategy for the tropical tunas in the Indian Ocean.

\section{Tropical tuna fisheries in the Indian Ocean}

Tropical tunas are the main target species of many industrial and artisanal fisheries in the Indian Ocean, representing 53\% of the total IOTC catches in 2018. Of the tropical tunas, skipjack tuna contributes the most to catches ( $\sim 53 \%)$, followed by yellowfin ( $\sim 38 \%)$ and bigeye ( $9 \%)$ tuna (IOTC, 2019a). Tuna fishing operations increased rapidly during the 1980s (Majkowski et al., 2011; Marsac et al., 2014), with tropical tuna catches growing from 146,483 tonnes (t) in 1980 to $560,308 \mathrm{t}$ in 1990 . At the beginning of the $20^{\text {th }}$ century, catches reached record levels, with 1,204,041 treported in 2005. Over the last decade, total catches have fluctuated between $~ 0.8-1.0$ million tonnes, with evidence of an increasing trend since 2015 with 1,130,359 t landed in 2018 (IOTC, 2019a) (Fig. 2a). Until the late 1960s catches of tropical tuna were dominated by Japan, but the large increase of catches during the 1980s was mainly driven by Taiwan, European Union, Maldives and Indonesia (Fonteneau, 2010). 
A characteristic of the Indian Ocean tropical tuna fishery is the relatively high contribution by the artisanal sector (e.g., handline, gillnet, and pole-and-line) with around of 50\% of total Indian Ocean tuna catches. Domestic fisheries represent the main livelihood for millions of people in developing countries of the eastern African coastal countries (van der Elst et al., 2005; Walmsley et al., 2006), and are of crucial importance for food and employment security (Christ et al., 2020). At the beginning of the 2000s, these fisheries accounted for $\sim 35 \%$ of the total catch, exceeding $50 \%$ in the $2010-2014$ period, after which it steadily decreased down to $43 \%$ in 2018 (Fig. 2b). The remaining catch is landed by industrial purse seiners and longliners (Murua et al., 2015; IOTC, 2019a). The contribution of each fishing gear to the catch varies among species. During the 2014-2018 period, skipjack tuna was mostly caught by industrial purse seiners $(\sim 40 \%)$, pole-and-line $(\sim 20 \%)$, and gillnet $(\sim 20 \%)$ whereas yellowfin was mostly caught by purse seiners $(\sim 36 \%)$, handline $(\sim 29 \%$, ) gillnet $(\sim 21 \%)$ and longline $(\sim 10 \%)$ (IOTC, 2019b). This indicates, that for these two species, catches are relatively evenly split between industrial and artisanal fisheries. By contrast, industrial fisheries account for the majority of bigeye tuna catches in the Indian Ocean; deepfreezing and fresh longline $(\sim 42 \%)$ and purse seiners $(\sim 31 \%)$ for the 2014-2018 period (IOTC, 2019a).

The majority of tropical tuna catches in the Indian Ocean are taken from the western region, with $\sim 80 \%$ of total catches occurring west of $80^{\circ} \mathrm{E}$ (i.e. FAO fishing area 51) in 2018 (IOTC, 2019a). However, location of catches can vary seasonally, interannually and between gear types (Kaplan et al., 2014). Longline fisheries operate throughout the entire Indian Ocean but catches of tropical tunas (primarily bigeye and yellowfin tuna) are predominantly taken between latitudes $30^{\circ} \mathrm{S}-20^{\circ} \mathrm{N}$, and peak from November to June (Fig.3). From November to February (Fig. 3a), high catches are widespread from west to east whilst they become concentrated in the Somali basin, north of $5^{\circ} \mathrm{S}$, from March to June (Fig. 3b). Although catches in Mozambique Channel and the Bay of Bengal, in all seasons, whereas bigeye is the primary target species Indian Ocean along a zonal region between South Africa and Australia, where bigeye (and albacore - not shown here) is caught as a bycatch of the southern bluefin fishery.

Purse seiners fishing activity is mainly concentrated in the western and central Indian Ocean, between latitudes $20^{\circ} \mathrm{S}-15^{\circ} \mathrm{N}$ (Fig.4). Skipjack tuna, and to lesser extent juveniles of yellowfin and bigeye tunas, are the predominant species caught by purse seiners fishing around fish aggregating devices (FADs) (Fig.4a, c 
and e), while yellowfin tuna dominate catches by purse seiners fishing on free-swimming schools (Fig.4b, $\mathrm{d}$ and f). From November to February, purse-seine catches on FADs are mainly in the western-equatorial Indian Ocean (Fig.4a), whereas purse seine catches on free-swimming schools increase around the Seychelles and Chagos archipelagos (Fig.4b). From March to June, the purse seine fishery operates in the western-equatorial area but extends as far south as the Mozambique Channel, which is a mixture of FAD and free school fishing (Fig.4c and d). During this period, tropical tuna catches by purse seiners are also higher off the East African continent relative to central Indian Ocean. During the southwest monsoon (JulyOctober, Fig.4e and f), catches shift northward $5^{\circ} \mathrm{S}$ again, being highest off Somalian coast up to the Seychelles archipelago.

Spatio-temporal patterns of activity of artisanal and semi-commercial fisheries cannot be described accurately because spatialized catch and effort data are not usually provided by the fleets. Within the Indian Ocean, the major pole-and-line fishery occurs in Maldives. This fishery is active all year round, targeting mainly skipjack tuna, and to less extent yellowfin tuna (Kolody and Adam, 2011; Miller et al., 2017). Maldivian hand-line also operates year around catching large yellowfin (Ahusan et al., 2016). The gillnet fishery of yellowfin tuna is also important in Sri Lanka, Pakistan and Iran, catching yellowfin and skipjack (IOTC, 2019b).

Since 2001 a significant progress has been made to reduce illegal, unreported, and unregulated fishing (IUU) within the Indian Ocean (Anganuzzi, 2004; Agnew et al., 2009), but the true extent of this problem may be underestimated due to paucity of information on non-industrial fisheries (Pauly and Zeller, 2016). Considering all fisheries in the region (not only tuna), reconstructed catch trajectories of the Indian Ocean differ considerably from the national landings data submitted to the FAO, especially in the western region (Pauly and Zeller, 2016). Inconsistencies between reported landings and reconstructed catch data for all taxa have been described for the south-western Indian Ocean (Temple et al., 2018), the Seychelles (Christ et al., 2020), Madagascar (Le Manach et al., 2016) and Somalia (Glaser et al., 2019).

\section{Life history}

Skipjack, yellowfin and bigeye tuna are classified into the Scombridae family, and together with the other 12 tuna, form the tribe Thunnini. Among the five genera that form this tribe, yellowfin and bigeye tuna belong to the genus Thunnus while skipjack tuna belongs to the genus Katsuwonus (Collette et al., 2001) (Fig. 5). Tunas (except Allothunnus sp.) are unique among bony fishes as they possess a counter-current 
heat exchanger system of retia mirabilia (i.e., a vein-arterial vascular system for heat conservation in muscles, viscera and brain tissue) that allows them to maintain the temperature of body tissue warmer than the surrounding waters (Collette et al., 2001). This endothermy, along with an elevated metabolic rate and frequency modulated cardiac output, support continuous, relatively fast swimming and reduce thermal barriers to habitat exploitation (Graham and Dickson, 2004). Skipjack and yellowfin tuna possess both central and lateral heat exchangers, although lateral retia mirabilia are relatively small. Bigeye tuna have no central heat exchanger, but a well-developed lateral heat exchanger (Carey et al., 1971; Graham, 1975), as well as an additional retia, the function of which is to increase the temperature of their viscera, eyes and brain. This allows bigeye to explore deeper and cooler waters than yellowfin or skipjack. These adaptations imply different life history traits and behaviours among the three species of tropical tuna (Díaz-Arce et al., 2016).

\subsection{Biogeography and habitat utilization}

Tropical tuna are circumtropical species that inhabit marine pelagic regions of the world's oceans between $45^{\circ} \mathrm{N}$ and $45^{\circ} \mathrm{S}$ (Fig. 6) (Sharp, 2001). Whereas adult yellowfin and bigeye tuna inhabit mid-ocean waters, juveniles of these species and skipjack tuna can be found both in coastal and offshore waters (Goujon and Majkowski, 2010). In the Indian Ocean, the three species are more abundant between the $15^{\circ} \mathrm{S}-15^{\circ} \mathrm{N}$ longitudinal band, the Arabian Sea and the Mozambique Channel, although they can also be found in other regions (Stéquert and Marsac, 1989; Lee et al., 2005; Kaplan et al., 2014). North of $10^{\circ} \mathrm{S}$, the Indian Ocean is characterized by a marked seasonality, due to the monsoonal system that determines the ocean circulation and climate (Schott and McCreary, 2001). Two monsoon periods occur annually, the southwest monsoon (June-September) and the northeast monsoon (December-March), with two inter-monsoon periods in between, one from April to May and the second from October to November (Schott et al., 2009; Han et al., 2014). In addition, there is a non-periodical mode of natural climate variability in the Indian Ocean, known as the Indian Ocean Dipole (IOD). This phenomenon is the result of sustained changes in the differences between sea surface temperatures (SST) of the western and eastern Indian Ocean (Saji et al., 1999). Both processes have an impact on the biological production and ecological processes of the area (Wiggert et al., 2006; Jury et al., 2010), and thus may affect the seasonal distribution and behaviour of tropical tuna in the Indian Ocean (Marsac and Le Blanc, 1998, 1999; Ménard et al., 2007b; Marsac., 2017). 
Although investigations of Indian Ocean tuna habitat preferences are scarce, experimental studies (Dizon et al., 1977; Sharp and Dizon, 1978; Sharp, 2001) have defined the main environmental preferences and physiological adaptation characterizing tuna habitats. As confirmed by other authors (e.g. Reygondeau et al., 2012; Arrizabalaga et al., 2015; Druon et al., 2017), tropical tuna prefer relatively warm and stratified waters. Skipjack, yellowfin and juvenile bigeye tuna inhabit the epipelagic zone, preferentially occupying the surface mixed layer above the thermocline and waters with sea surface temperatures (SSTs) ranging from 18 to $31^{\circ} \mathrm{C}$ (Barkley et al., 1978; Stéquert and Marsac, 1989; Pecoraro et al., 2016). Particularly in the Indian Ocean, adult yellowfin tuna preferred habitat has been described to be at depths between 100 and $180 \mathrm{~m}$ and water temperatures between $15.0-17.9^{\circ} \mathrm{C}$ (Song et al., 2008). By contrast, adult bigeye tuna inhabit mesopelagic waters, and prefer depth and water temperatures between 240 and $280 \mathrm{~m}$ and 12 to 13.9 ${ }^{\circ} \mathrm{C}$, respectively (Song et al., 2009). Tropical tuna larvae require warmer water (Conand and Richards, 1982; Wexler et al., 2011; Kim et al., 2015), being confined to narrower habitat ranges than juveniles and adults (Reglero et al., 2014) (Fig. 6). The isothermal boundary of tropical tuna spawning areas is $>24^{\circ} \mathrm{C}$ (Schaefer, 2001), although Reglero et al., (2014) suggested that this assumption should be revisited as they found a lower tolerance for tropical tuna larvae of $20^{\circ} \mathrm{C}$. Larval occurrence seems to increase at intermediate values $\left(0.01-0.06 \mathrm{~m}^{2} \mathrm{~s}^{-2}\right)$ of eddy kinetic energy (Kimura et al., 2004; Reglero et al., 2014).

Despite temperature preferences restricting tropical tuna spatial distribution, electronic tagging has shown that these species are able to perform deep dives into colder waters (e.g. Schaefer et al., 2009). Depth preference is known to change according to body size (Barkley et al., 1978; Graham and Dickson, 2004) and time of the day (Evans et al., 2008). In the Indian Ocean, deep diving behaviour has only been studied in yellowfin tuna; archival tagging of adults showed that large individuals can dive to depths in excess of $1000 \mathrm{~m}$ (Dagorn et al., 2006). Oxygen availability also limits the bathymetric range of tropical tuna species. Skipjack and yellowfin tuna have limited tolerance to low levels of dissolved oxygen (Barkley et al., 1978; Graham and Dickson, 2004), while bigeye tuna can tolerate, and even favour, less oxygenated (e.g. $<0.2$ mmol/L) waters (Sharp and Dizon, 1978; Graham and Dickson, 2004; Song et al., 2009; Arrizabalaga et al., 2015). These species-specific physiological abilities and tolerances to environmental characteristics of their vertical habitat, result in exploitation of distinct ecological niches at different stages of their lifehistories. 
Tropical tuna have been described as energy speculators, meaning that high rates of energy expenditure are invested to obtain even higher rates of energy (Korsmeyer and Dewar, 2001). Thus, their lifestyle implies the necessity for searching large areas of their habitat in search of food (Dickson, 1995). As such, tropical tunas are visual opportunistic predators that feed on a wide variety of prey (Olson et al., 2016; Duffy et al., 2017); the particular composition will be mainly determined by body size, location, period and feeding depth of each species (Ménard et al., 2006; Olson et al., 2016). In the Indian Ocean, studies analyzing the composition and size of the prey in stomachs of skipjack, yellowfin and bigeye tuna, are limited to the western region.

As larvae and small juveniles, tropical tuna diet consists of planktonic organisms inhabiting the shallow mixed layer (Young and Davis, 1990; Graham et al., 2007). Tuna larvae are precocious feeders; skipjack larvae start feeding two days after hatching (Matsumoto et al., 1984), while rotifers have been found in digestive tracks of 4-day old yellowfin tuna larvae (Kaji et al., 1999). With the development of thermal capability, a progressive diet shift occurs (Kaji et al., 1999; Graham et al., 2007). Maldeniya (1996) found a gradual increase in fish consumption in yellowfin tuna $>40 \mathrm{~cm}$ fork length (FL) from Sri Lanka. This ontogenetic shift in diet has also been reported for bigeye tuna of the Indian Ocean: the diet of juvenile bigeye tuna consists mainly on stomatopod crustaceans, while piscivory increases in larger specimens (Duffy et al., 2017). Juveniles of skipjack, yellowfin and bigeye tuna can be found in mixed schools feeding at the surface, generally near the continental shelf, islands or around floating objects (IOTC, 2017a, 2017b, 2017c). Trophic markers revealed high potential of resource overlap between smaller individuals of these species (Sardenne et al., 2016).

In contrast, adults consume a larger range of prey sizes (mainly small fish, cephalopods and crustaceans) (Ménard et al., 2007a; Jaquemet et al., 2011; Olson et al., 2016), and exhibit predation plasticity depending on prey availability between times and locations (Olson et al., 2016; Duffy et al., 2017). Changes in diet composition with distance from the coast have been reported for skipjack and yellowfin tuna (Smale, 1986). Small pelagic fish (Cubiceps pauciradiatus, Sardinella ocellata and Engraulis capensis) dominate by volume for skipjack and yellowfin tuna diets near the shore (Smale, 1986; Potier et al., 2008), whereas in open-ocean waters the ommastrephid cephalopod Lycotheuthis diadema also forms part of the diet (Smale, 1986). For yellowfin tuna feeding in offshore waters, the pelagic crab Charybdis smithii was found to be 
the dominant prey item (Potier et al., 2007; Romanov et al., 2009). Long-term dietary changes have been observed for open-water surface swimming skipjack and yellowfin tuna in the western-equatorial Indian Ocean, shifting from fishes to crustacea. During the 1980's, the main prey item was the small cupleid Engraulis japonicus (Roger, 1994), whereas in the 2000s the stomatopod Natosquilla investigatoris was by far the dominant prey item (Potier et al., 2002, 2004) for yellowfin and skipjack tuna captured in the Seychelles archipelago.

Foraging depth also influences the type of prey consumed by tropical tuna species (Kornilova, 1980). The stomach content of surface swimming yellowfin and bigeye tuna was dominated by the stomatopod $N$. investigatoris. Additionally, surface caught yellowfin tuna showed preference for fish (scombrids) and bigeye tuna for squids (ommaestrephids) (Potier et al., 2004). Deep swimming bigeye tuna showed a generalized feeding behavior with no dominant prey species found in their stomach. For yellowfin tuna swimming in deep waters both types of feeding strategies were found (i.e. generalized and specialized), with specialized feeders favoring crustaceans such as crab larvae or the swimming crab Charybdis edwardsi (Potier et al., 2004). Specialized feeding behaviors have also been reported in reproductive females of yellowfin tuna from Atlantic, Pacific and Indian Oceans (Bard et al., 2002; Flynn and Paxton, 2013; Zudaire et al., 2015). During the spawning period, the latter seem to feed more intensively on lipid-rich fish, particularly on cigarfish, Cubiceps pauciradiatus (Zudaire et al., 2015).

Stomach content analyses also indicate differential diel feeding behavior among species (Fig. 7). Skipjack tuna feed during the day on prey that remain in shallower depths (0 to $200 \mathrm{~m}$ according to Roger, 1994), with a bimodal peak of feeding activity around crepuscular periods (Olson et al., 2016). Peak feeding of yellowfin and bigeye tuna occurs between 8 a.m. and 12 noon, although stomach fulness indices show that yellowfin tuna feed throughout the day, while bigeye tuna is, in general, a daytime feeder (Olson et al., 2016). Carbon and nitrogen isotopic signatures measured in muscles of the three species of tropical tuna in the western Indian Ocean, suggested that bigeye tuna have a higher trophic position than skipjack and yellowfin tunas (Olson et al., 2016; Sardenne et al., 2016). Due to their relative tolerance to lower temperature and oxygen levels, bigeye tuna are able to prey at greater depths and lower light intensity (Stobberup et al., 1998). Finally, skipjack tuna possess greater daily ratios of ingestion (3.5-4.2\%, percentage of body weight per day), than yellowfin (1.1-2.0\%) and bigeye (0.6-3.6\%) tunas (Olson et al., 2016) .Research on the trophic ecology of tropical tuna of the western Indian Ocean indicate some degree 
of resource portioning both intra- and interspecifically, which allows the exploitation of different trophic niches and effectively reduces the potential for food competition.

\subsection{Age and Growth}

Several approaches have been used to estimate growth of tropical tunas, including modal analyses of length frequencies, the examination of daily and annual rings in calcified structures (e.g. otoliths, spines, vertebrae) and information obtained from tag and recapture data (for an exhaustive review see Murua et al., 2017). In addition, some growth models have combined the methods described above in an integrated model, with the aim of reducing the biases associated with any single approach (Dortel et al., 2015; Eveson et al., 2015).

Tropical tuna possesses a relatively high growth performance, characterized by having both high growth rate coefficients $(k)$ and, in the case of yellowfin and bigeye tuna, high asymptotic fork lengths $\left(\mathrm{L}_{\infty}\right)$. Skipjack tuna is considered the fastest growing species of all tunas (Murua et al., 2017). In the Indian Ocean, estimated $\mathrm{k}$ values range between 0.23 and 1.41 year $^{-1}$ and $\mathrm{L}_{\infty}$ values from 60.6 to $94.8 \mathrm{~cm}$ FL, but most growth curves reported $\mathrm{k}$ values $>0.4$ and $\mathrm{L}_{\infty}<82.5 \mathrm{~cm}$ FL (Fig.8). Yellowfin tuna is the second fastest growing tuna species but has a higher growth performance than skipjack tuna. Reported $\mathrm{k}$ and $\mathrm{L}_{\infty}$ values in the Indian Ocean range from 0.18 to 1.54 and from 123.6 to 272.7, respectively (Murua et al., 2017). Mean reported $\mathrm{k}$ value was 0.34 and most $\mathrm{L}_{\infty}$ values were $\sim 160 \mathrm{~cm}$ FL (Fig.8). Fewer studies have reported growth parameters of bigeye tuna in the Indian Ocean. They have slower growth rates than the other two tropical tuna species, reported $\mathrm{k}$ values ranging from 0.06 to 0.45 , with a mean $\mathrm{k}$ of 0.22 (year ${ }^{-1}$ ) (Murua et al., 2017). Reported asymptotic lengths range from 150.9 to $423.0 \mathrm{~cm}$ FL (Fig.8), although mean reported $\mathrm{L}_{\infty}$ values were $\sim 190 \mathrm{~cm}$ FL. The large variations in growth parameter estimates among studies are probably due to the different techniques used (i.e. disagreements between otoliths and spines), size of analysed fish (i.e. different ages can produce different parameters), lack of inter-laboratory calibrations (i.e. different readers might produce different results), sampling strategy and/or sampling coverage (i.e. spatio-temporal variability in growth). All these factors caution against extrapolating the growth model outside the range of the data used for parameter estimation.

Previous studies have indicated that tropical tuna may pass through different stanzas of growth rates during their life (Fonteneau, 1980; Bard, 1984; Marsac, 1991). This hypothesis was revisited and supported by Dortel et al., (2015) and Eveson et al., (2015) for the three tropical species in the Indian Ocean. In the case 
of skipjack tuna, the two-stanza growth model is characterized by a rapid growth in the first stage, followed by a slower growth in the second stage (Eveson et al., 2012, 2015) (Fig.9a). Due to the initial high growth rates, skipjack tuna can reach $\sim 45 \mathrm{~cm}$ FL in the first year of life, and between $50-65 \mathrm{~cm}$ FL in the second year, from which the growth rates diminish (Tanabe et al., 2003). Similar results were obtained by Kayama et al., (2004) for skipjack in the eastern Indian Ocean (45 cm FL), although reported sizes for the second year were smaller (50-55 cm FL). By contrast, yellowfin and bigeye tuna have a phase of slower growth rate as juveniles, followed by a stanza of a higher growth rate. The first slow-growth phase in yellowfin tuna (around $2.1 \mathrm{~cm} \mathrm{month}^{-1}$ ) lasts until they reach $56-70 \mathrm{~cm} \mathrm{FL}$. After a quick transition, yellowfin tuna then grow at a faster rate $\left(4.1 \mathrm{~cm} \mathrm{month}^{-1}\right)$ until they reach approximately $145 \mathrm{~cm} \mathrm{FL}$, with a progressive decrease in the growth rate with size thereafter $\left(0.01 \mathrm{~cm} \mathrm{month}^{-1}\right)($ Fig. $9 \mathrm{~b})$ (Olivier, 2002; Dortel et al., 2015; Eveson et al., 2015). In bigeye tuna, the transition between slow- and fast-growth phases occurs at a similar length (around $60 \mathrm{~cm} \mathrm{FL),} \mathrm{however} \mathrm{this} \mathrm{transition} \mathrm{is} \mathrm{more} \mathrm{gradual} \mathrm{(Fig.9c)} \mathrm{(Eveson} \mathrm{et} \mathrm{al.,} \mathrm{2015).}$ There is evidence for sexual-dimorphism in growth in Indian Ocean yellowfin and bigeye tuna (Stéquert et al., 1996; Nootmorn, 2004; Nootmorn et al., 2005; Zudaire et al., 2013a), with male individuals attaining larger maximum sizes compared to females (Farley et al., 2006; Shih et al., 2014; Eveson et al., 2015).

Bigeye tuna possess the greatest life expectancy among tropical tuna. Based on otolith interpretation and tagging studies, Farley et al. (2006) proposed a maximum age of at least 16 years for bigeye tuna caught in the eastern Indian Ocean, based on validated annual bands. Maximum age for skipjack however is $\sim 6-7$ years, whereas reported longevity for yellowfin tuna is in the order of 9 years in the Indian Ocean (Shih et al., 2014; Murua et al., 2017). However, bomb radiocarbon dating has recently validated age estimates of 16-18 years for yellowfin tuna in the Atlantic Ocean (Andrews et al., 2020). After this, our understanding on maximum ages of yellowfin tuna in the Indian Ocean should be revisited.

\subsection{Reproductive biology}

Tropical tunas are oviparous, have an asynchronous oocyte development and spawn multiple batches of oocytes each spawning season (Joseph, 1963; Hunter et al., 1986; Stéquert and Ramcharrun, 1995; Schaefer, 2001). In terms of reproductive strategy, female skipjack tuna follow what has been described as an income breeder strategy, that is, required energy is obtained directly from food intake rather than from accumulated energy reserves (Grande et al., 2016). Female yellowfin tuna however, are considered to be mixed income-capital breeders (Zudaire et al., 2014). Analyzing lipid allocation of yellowfin tuna from the 
western Indian Ocean, Zudaire et al., (2014), found that required energy for gonad development depended mainly on the energy provided by feeding during the prolonged spawning period and, to a lesser extent, on stored lipids. For bigeye tuna, there are no studies addressing the breeding strategy and energy allocation to reproduction in the Indian Ocean. However, Sardenne et al., 2017 suggested an income-capital breeding strategy for bigeye tuna after concluding that liver neutral fatty acids levels were similar to those from yellowfin.

Mean size at maturity, i.e., length at which $50 \%$ of female skipjack tuna are classed as mature $\left(\mathrm{L}_{50}\right)$, has been estimated at between $39.9 \mathrm{~cm}$ and $42.0 \mathrm{~cm}$ FL in the western Indian Ocean (Stéquert, 1976; Grande et al., 2014). In the case of yellowfin tuna, $\mathrm{L}_{50}$ values range between 75 and $114 \mathrm{~cm}$ FL. In the western Indian Ocean, $\mathrm{L}_{50}$ of yellowfin tuna was estimated at $75.0 \mathrm{~cm}$ to $102.0 \mathrm{~cm} \mathrm{FL}$, depending on the threshold oocyte development stage considered to indicate maturity (i.e., cortical alveolar vs. vitellogenic) (Zudaire et al., 2013a). In the eastern and west-central Indian Ocean, $\mathrm{L}_{50}$ for females has been estimated at $109.6 \mathrm{~cm}$ and $114.0 \mathrm{~cm}$ respectively, whereas $\mathrm{L}_{50}$ reported for males was at $104.9 \mathrm{~cm}$ and $120.0 \mathrm{~cm}$ FL (Nootmorn et al., 2005; Zhu et al., 2008). Similarly, different $\mathrm{L}_{50}$ estimations have been reported for bigeye tuna in the Indian Ocean. Mean size at maturity estimates range from $88.1 \mathrm{~cm}$ FL (females) and $86.8 \mathrm{~cm}$ FL (males) in the eastern Indian Ocean (Nootmorn, 2004) to 102.0 (females) and 119.3 (males) cm FL in the western Indian Ocean (Zhu et al. 2011; Zudaire et al. 2016).

Tropical tuna show an indeterminate fecundity type (i.e., oocyte maturation is continuous during their extended spawning periods) (Grande et al., 2012; Zudaire et al., 2013b). Studies carried out in the western Indian Ocean show that skipjack tuna has a higher mean relative batch fecundity, $140.0 \pm 64.0$ oocyte $\mathrm{g}^{-1}$ of

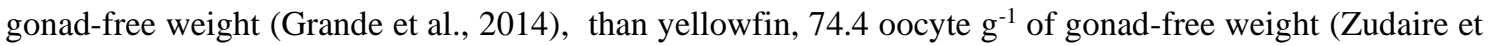
al., 2013a), and bigeye tuna, 11.5 \pm 7.1 oocyte $\mathrm{g}^{-1}$ of gonad-free fish (Zudaire et al., 2016). Reported individual fecundity for skipjack tuna range from 80,000 oocytes for a $44 \mathrm{~cm}$ FL female to 1.25 million oocytes for a large (75 cm FL) female in the western Indian Ocean (Stéquert and Ramcharrun, 1995). Grande et al. (2010) estimated batch fecundity from 100,828 oocytes to 627,325 oocytes in female skipjack ranging from 32 to $68 \mathrm{~cm}$ FL. In the case of yellowfin tuna, estimated batch fecundity varied from 0.3 to 5.3 million oocytes in females from the eastern Indian Ocean (Nootmorn et al., 2005). In the western Indian Ocean mean batch fecundity for female yellowfin tuna 79-147 cm FL was estimated at 3.1 million oocytes (Zudaire et al., 2013a). Finally, mean batch fecundity of bigeye tuna in the western Indian Ocean has been estimated at $0.75 \pm 0.52$ million oocytes (Zudaire et al., 2016). Spawning frequency of tropical tuna species 
in the Indian Ocean has not been reported yet, but in the Pacific Ocean the mean spawning interval has been determined as 1.18, 1.53 and 1.09 days for skipjack, yellowfin and bigeye tuna respectively (Schaefer, 2001).

Timing of spawning varies in relation to the geographical distribution of the three species of tropical tuna (Table 1). In the western Indian Ocean, spawning of skipjack tuna occurs throughout the year, with peaks of intensity between November-March and June-July, coinciding with the northeastern and southwestern monsoon period respectively (Stéquert et al., 2001; Grande et al., 2014). Koya et al., (2012) also observed year-round spawning in Indian waters but reported a peak in activity between December-March and a smaller peak from June to August. Spawning period seems to shorten as the distance from equator increases (Matsumoto et al., 1984). Yellowfin tuna predominantly spawn from November to February in equatorial waters, primarily on spawning grounds west of $75^{\circ} \mathrm{E}$ (Shung, 1973; Hassani and Stéquert, 1991; Zudaire et al., 2013a). A shorter spawning period (i.e., from December to February) has been reported for females smaller than $100 \mathrm{~cm}$ FL (Zudaire et al., 2013a). The offshore waters of Mozambique Channel and the eastern Indian Ocean are also known as secondary spawning grounds. In the east, spawning is prolonged from November until April (John, 1995; John et al., 1998; Nootmorn et al., 2005). Secondary spawning peaks have also been described; in June for the western Indian Ocean, between April and June around Sri Lanka, and from October to December off northern Australia and Madagascar (Stéquert and Marsac, 1989; Stéquert et al., 2001; Zudaire et al., 2013a). Bigeye tuna from different areas of the Indian Ocean possess differences in spawning seasonality. In equatorial waters of the Indian Ocean, bigeye tuna are able to spawn year round (Kume et al., 1971; Stobberup et al., 1998). In the eastern Indian Ocean, the spawning season is reported from December to January, with another peak in June (Nootmorn, 2004), whereas in the western Indian Ocean, high reproductive activity has been observed from January to March (Zudaire et al., 2016).

\section{Stock structure}

There is little information available to determine whether the tropical tuna of the Indian Ocean constitute single or several stocks. Current stock assessments are conducted assuming that there are single, Indianwide stocks of skipjack, yellowfin, and bigeye tuna; and that there is no exchange of fish among Atlantic, Indian and Pacific Oceans. This assumption is based on the results obtained from the Indian Ocean Regional Tuna Tagging Program (RTTP-IO) that suggest rapid and large-scale movements of the three tropical species in the Indian Ocean (Fonteneau and Hallier, 2015). However, findings obtained from other 
approaches (e.g. fishery data and genetic markers) show a more fragmented population structure than typically assumed in the assessment and management of these species. The aim of this section is therefore to compile and evaluate the scientific evidence available on Indian Ocean skipjack, yellowfin, and bigeye stock structure.

\subsection{Fisheries Data}

Spatial and temporal distribution of catch and effort data from the commercial fishery can be used as a crude indicator of stock structure if, for example, strong geographic differences in age composition, relative abundance and/or distribution are reported. Early studies used catch data distribution and fishery length data of skipjack, yellowfin and bigeye tuna to describe the stock structure in the Indian Ocean. A study based on size composition of skipjack caught by longline vessels in the Indian Ocean during 1972-1975, reported relatively smaller specimens in the central and eastern Indian Ocean (Pillai and Silas, 1979). Similarly, analysing Japanese longline fishery data (1961-1965), Morita and Koto, (1970) suggested a twostock structure for the Indian Ocean yellowfin tuna; the western and eastern stocks separated approximately at $100^{\circ} \mathrm{E}$ and possibly mixing in adjacent waters. Later, Nishida (1992) concluded that there were two major and two minor stocks of yellowfin tuna in the Indian Ocean, using catch-per-unit-effort (CPUE), agespecific CPUE and size variations obtained from longline fishery data. The two major stocks (named western and eastern) were defined at $40^{\circ}-80^{\circ} \mathrm{E}$ and $80^{\circ}-120^{\circ} \mathrm{E}$ respectively. The two minor stocks were defined westward $40^{\circ} \mathrm{E}$ and eastward of $120^{\circ} \mathrm{E}$, and named far western and far eastern respectively, with the latter possibly being part of the Pacific stock. In the case of the bigeye tuna, a single stock was suggested for the Indian Ocean, based on the distribution, size composition and sexual maturity of the fish, although some differences between eastern and western bigeye tuna were reported (Kume et al., 1971).

\subsection{Morphometric and meristic characters}

Phenotypic variation in anatomical characters have historically been used for stock identification purposes. Morphometrics analyse quantitatively the size and shape of the body, whereas meristic analyses refer to countable traits (e.g. fin rays, scales in rows, gill-rakers and myomeres). By comparing different body characters of yellowfin tuna collected from six grounds in the Indian Ocean, Kurogane and Hiyama (1958) suggested a 3-stock structure, one stock in the western Indian Ocean and two in the eastern Indian Ocean, with a strong intermingling between $80-100^{\circ} \mathrm{E}$. Although a preliminary study demonstrated the potential 
utility of otolith shape variation for skipjack tuna stock structure identification in the Indian Ocean (Wujdi et al., 2017), this marker has not yet been used for tropical tuna stock structure analyses in this ocean.

\subsection{Parasites}

Geographical variation in species composition and abundance of parasites has been used as a natural tag for fish stock structure analyses. This is because parasite occurrence depends on biogeography, distinct environmental tolerances of parasites, differential availability of intermediate hosts, and basically different life history characteristics of the fish stocks per se (Catalano et al., 2014). Lestari et al. (2017) found 7 potential parasites that might be useful to discriminate juvenile yellowfin and bigeye tuna from Indonesian waters. More recently parasite data from juvenile yellowfin and bigeye tuna from the Maldives proved to be significantly different from those belonging to Indonesian waters (Moore et al., 2019). Therefore, authors have suggested movements of yellowfin and bigeye from the Maldives archipelago into the eastern Indian Ocean were limited.

\subsection{Genetics}

With the development of new molecular techniques, the use of molecular markers such as allozymes, mitochondrial or nuclear DNA polymorphisms have increased in stock identification studies. Each of these markers presents a series of advantages and limitations, but all have been used in Indian Ocean tropical tuna stock structure studies. Often, the use of different techniques and sampling designs provide contradictory results, especially when the organism being studied has a widespread distribution and/or complex natural history, as is the case of skipjack, yellowfin and bigeye tuna (Kumar and Kocour, 2015).

For example, Menezes et al. (2006) found high levels of genetic differentiation between skipjack tuna collected from the east coast of India and the coast of Japan (Pacific Ocean) after using PCR-RFLP analysis of the mitochondrial D-loop region. However, when using nuclear microsatellite markers, there was no differentiation between samples from the two aforementioned regions (Menezes et al., 2008). Also at the inter-oceanic scale, Fujino et al. (1981) found significant differences in allozyme allele frequencies in skipjack from the Indian Ocean compared to those collected both from the Atlantic and western Pacific Oceans. Additional studies comparing Atlantic and Pacific Ocean skipjack tuna revealed a high degree of genetic similarity among these two oceans (e.g. Graves et al., 1984; Ely et al., 2005). Few genetic studies have been conducted on skipjack tuna population structure within the Indian Ocean to date. Although limited to a regional scale, these studies reported the presence of heterogeneous groups of skipjack in the 
north-central and eastern Indian Ocean. In adjacent waters of Sri Lanka, Maldives and Laccadive islands, two differentiated stocks have been described after analysing patterns of genetic variation with both a mitochondrial gene and six microsatellite loci (Dammannagoda et al., 2011). Additionally, sequence data of the mitochondrial D-loop region revealed the presence of four clades of skipjack tuna in the east and west coasts of India (Menezes et al., 2012). Although both studies failed to find a clear spatial pattern among samples, Dammannagoda et al. (2011) proposed different hypotheses for the physical mixture of these two distinct skipjack tuna clades around Sri Lanka: (i) different stocks may spawn in distant areas of the Indian Ocean, and juveniles subsequently separately migrate towards Sri Lanka, which is a highly productive foraging ground and (ii) the monsoonal currents in the Indian Ocean could drive the larvae towards this area by passive transport. Menezes et al. (2012) suggested that the absence of a symmetrical pattern of haplotype distribution in the analysed clades could be due to secondary contact and interbreeding of populations after being geographically isolated for a prolonged period. In the eastern Indian Ocean, the results from three microsatellite loci suggest the presence of two stocks of skipjack tuna in Indonesian waters, with genetic differentiation between skipjack from west of Sumatra and south of Java (Jatmiko et al., 2019).

In the case of yellowfin tuna, the use of different genetic markers has also lead to discordances both at intraand inter-oceanic patterns of differentiation (Pecoraro et al., 2016). Using allozyme markers, Smith et al. (1988) described genetic heterogeneity between yellowfin tuna from the Pacific and Indian Oceans. However, Wu et al. (2010) did not detect any genetic differentiation between yellowfin tuna from the western Pacific and western Indian Oceans using mitochondrial markers. A global genetic study of yellowfin tuna combining both allozymes and mitochondrial DNA, suggested differentiation between the Atlantic, Indian, west-central Pacific and east Pacific oceans (Ward et al., 1997). Recently, the use of next generation sequencing has shed new light on the global population structure of yellowfin tuna. Using genomic wide single nucleotide polymorphisms (SNPs), Pecoraro et al. (2018) identified genetic differentiation of yellowfin tuna between Indian, Atlantic and Pacific Oceans. Moreover, genomic analyses have revealed asymmetrical dispersal from the Indian Ocean yellowfin tuna into the Atlantic and highlighted that yellowfin tuna found along all the South African coast are derived from the Indian population (Barth et al., 2017; Mullins et al., 2018). This connection was also noticed during the RTTP-IO with a few yellowfin tuna tagged in Tanzania that were recovered in the southern Agulhas current, along the South African coasts. In light of this evidence, Mullins et al. (2018) proposed that the current operational 
boundary for management between the Atlantic and Indian stocks should be revisited. Using genome wide SNPs, Barth et al. (2017) found genetic differentiation of yellowfin tuna from the Arabian Sea with respect to those from the Atlantic and Indo-Pacific. Results from genome wide SNPs also indicate a marked genetic difference between samples from the central Indian Ocean (Maldives) and the western Pacific Ocean, but not between samples from eastern Indian Ocean (Indonesia) and the western Pacific Ocean (Proctor et al., 2019). Proctor et al. (2019) proposed that the observed pattern of differentiation may indicate limited gene flow between the central and eastern Indian Ocean, with more pronounced gene flow among Indonesian and Western Pacific regions. At intra-oceanic scale, the comparison between samples from the westernmost and easternmost parts of the Indian Ocean, did not reveal any genetic differentiation (Chow et al., 2000a; Nishida et al., 2001). In contrast, mitochondrial and nuclear microsatellite loci variations of yellowfin tuna collected from six fishing grounds around Sri Lanka and one in Maldives, suggested the existence of discrete yellowfin tuna populations in the northwest Indian Ocean (Dammannagoda et al., 2008). Additionally, a study using the mitochondrial D-loop region supported the presence of three genetically different stocks of yellowfin tuna in the north Indian Ocean (Kunal et al., 2013).

Global genetic studies have also reported an inter-oceanic division between Atlantic and Indo-Pacific bigeye tuna both by analysing nuclear (Durand et al., 2005) or mitochondrial (Alvarado-Bremer et al., 1998; Chow et al., 2000b; Martinez et al., 2006) markers. Indo-Pacific bigeye tuna intermingle off southern Africa with Atlantic bigeye tuna (Chow et al., 2000b; Durand et al., 2005). However, Gonzalez et al., 2008 found discordant results when analysing genetic structuring and migration patterns of Atlantic bigeye tuna. Microsatellite loci supported a single worldwide panmictic bigeye tuna population, whereas mitochondrial markers show genetic differentiation between Atlantic and Indo-Pacific bigeye tuna populations, as previous studies did. However, a recent study using SNP data proved restricted connectivity between Indian Ocean (central and eastern) and the western Pacific Ocean bigeye tuna, with samples from central Indonesia having limited connectivity also with the previous areas (Proctor et al., 2019). Few studies have been carried out to describe the structure of bigeye tuna in the Indian Ocean. Most of them did not observe signs of heterogeneity, supporting the existence of a single panmictic population in this ocean. After analysing variations in mitochondrial DNA polymorphisms and seven microsatellite loci of bigeye tuna distributed in the eastern, central and western Indian Ocean, minimal and generally non-significant genetic differentiation was reported (Appleyard et al., 2002). Likewise, a study using mitochondrial DNA data from bigeye tuna sampled among 4 regions (Cocos Islands, south-eastern Indian Ocean, south-western Indian 
Ocean and Seychelles) failed to detect any differences between areas (Chiang et al., 2008). A local study carried out in distinct locations off Indonesia however, reported the existence of two genetically distinct groups of bigeye tuna in the eastern Indian Ocean, based on genetic distances and RFLPs mitochondrial Dloop region (Nugraha et al., 2010). Similarly, SNP analyses indicated a gradient in geneflow between the Indonesian archipelago, the eastern Indian Ocean, and the Maldives, consistent with an isolation by distance model (Proctor et al., 2019).

Overall, it seems that results obtained from the application of a single type of molecular marker should be interpreted with caution. For the three species of tropical tunas, different population structure was suggested depending on the analyses. In general, results relying on mitochondrial DNA showed higher heterogeneity than those based on nuclear DNA. Qiu et al. (2013) hypothesized that this mito-nuclear discordance found in tuna species, may be a result of behavioural differences between sexes rather than a misuse of the chosen marker; mitochondrial DNA is inherited from females which may present greater philopatric behaviour. If so, female philopatry would have enhanced mitochondrial DNA diversity, while male-biased dispersal would have homogenized group differences that could be revealed in the nuclear genome (Qiu et al., 2013). The current rise of next generation sequencing (NGS) based genotyping methods, presents a cost-effective alternative to increase the precision in detecting small genetic differences (Rodríguez-Ezpeleta et al., 2019). At local scale, NGS techniques have been already used to discriminate among yellowfin tuna populations of the Pacific Ocean (Grewe et al., 2015). To date no studies of that kind have been published in the Indian Ocean. It is recognised that this technique, combined with a structured basin-wide sampling design, would provide a powerful tool to finally reveal a clear picture of the population structure of tropical tunas in this ocean.

\subsection{Otolith microchemistry}

Chemical composition of fish otoliths and other calcified structures (e.g. scales, fin-rays and spines), have been recognised as useful natural markers to discriminate among groups of fish that have inhabited different environments. While genetic analyses provide information over evolutionary timescales, otolith chemistry inform over ecological time frames (i.e., larval history, individual life span...) (Campana, 1999, 2005; Tanner et al., 2016). Thus, this technique is useful to identify differences in natal origin or migration patterns, revealing complex population structures and biologically meaningful units. Despite their importance to delineate fish stocks, otolith microchemistry has barely been used in tropical tuna structure 
analyses. Natal origin studies have been conducted for bigeye tuna of the Pacific Ocean (Rooker et al., 2016), and for yellowfin tuna both in the Pacific (Wells et al., 2012; Rooker et al., 2016) and the Atlantic Oceans (Shuford et al., 2007; Kitchens, 2017). Arai et al. (2005) described movements and life history patterns of skipjack tuna in the Pacific Ocean based on otolith Sr:Ca ratios. In the Indian Ocean, initial investigations of otolith trace element data proved useful for yellowfin tuna stock delineation (ArtetxeArrate et al., 2019). Moreover, the study detected some level of separation between two potential nursery regions (Seychelles-Somalia and Mozambique Channel) using young-of-the-year (YOY) yellowfin tuna from the western Indian Ocean. Similarly, otolith microchemistry analyses showed restricted movements of yellowfin and bigeye tuna of the eastern Indian Ocean during their first 4-6 months of life (Proctor et al., 2019). Otolith isotopic analyses, and particularly oxygen isotope $\delta_{18} \mathrm{O}$ composition, might also be useful in discriminating among fish of different origins in the Indian Ocean (Fig.10). Both techniques need now to be expanded at ocean basin scale, to help clarify unresolved population structure of the three species of tropical tuna in this ocean.

\subsection{Tagging}

Artificial tags have commonly been used as an indirect approach to identify stock structure. Tagging provides information of fish dynamics (e.g. movement range and pattern), and hence can be a useful tool to infer the degree of mixing among potential stocks. There is an extensive tagging data collection in the Indian Ocean, as tagging programs were initiated in the Maldives in 1990-1994 and continued 15 years later (2005) when the IOTC started a large-scale Indian Ocean Regional Tuna Tagging Program (RTTPIO) (Murua et al., 2015).

Results obtained from these programs describe fast and large-scale skipjack movements, with an average monthly distance of 1066 miles between tagging and recovery positions in the first year (Fonteneau and Hallier, 2015). Skipjack tagged in Tanzania showed the larger and fastest migrations (e.g. average distances of 1129 miles after one month at liberty), followed by skipjack tagged in Mozambique Channel (an average of 894 miles travelled). Despite the rapid movements described for skipjack tuna tagged in the Mozambique Channel, most tagged tuna returned to this area within one year, coinciding with the March-May fishing season, a pattern that was recurrent over the studied years (Fonteneau and Hallier, 2015). Authors suggested that rather than a random movement, this return may correspond to a fidelity behavior towards a feeding area. Average distances travelled were shorter in the Seychelles tagging (698 miles) and the lowest for 
skipjack tuna tagged in the Maldives (358 miles) (Fonteneau, 2014). This result is very similar to the results of the early Maldivian tagging program carried out between 1990 and 1995 (Adam and Sibert, 2002). Although the heterogeneity of skipjack movement patterns was high, Adam and Sibert (2002) found evidences of low emigration rates from Maldives to the rest of the Indian Ocean. This could be because skipjack tuna travel longer distances in the open ocean than in archipelagic waters (Fonteneau, 2014). This is the case for the Maldives, which comprises a network of nearly 1200 islands. In addition, the presence of numerous anchored FADs in this region, under which skipjack aggregate, may be reinforcing the "island effect", reducing the distance travelled by this species. Conversely, drifting FADs may increase the mobility of skipjack in other areas (Marsac et al., 2000; Hallier and Gaertner, 2008). Thus, based on these results, Fonteneau (2014) proposed that future stock assessment of the skipjack population should consider at least 4 different regions with differential mixing rates in the Indian Ocean: southwest Indian Ocean, northwest Indian Ocean, central Indian Ocean and eastern Indian Ocean.

The evidence of fast and large movements of yellowfin tuna reported by the RTTP-IO supports the assumption of a single well-mixed yellowfin tuna population within the Indian Ocean (IOTC, 2017c). For instance, short-term recoveries were associated with relatively long distances (249 miles on average), about 5 times longer than the distances of short-term recoveries in other oceans (Fonteneau and Hallier, 2015). Past tagging studies showed that there was exchange of yellowfin tuna between the central and the western Indian Ocean (Yano, 1991) and movements of yellowfin from Maldives to Sri Lanka (Nishida et al., 1998). However, Kolody and Hoyle (2013) found that tag releases from the Maldives area were sometimes retained there, without mixing into the rest of the population. It is also noteworthy that most tagging events occurred in the western part of the Indian Ocean and few recoveries have been reported from the eastern part. Langley and Million (2012) suggested that the $28-29^{\circ} \mathrm{C}$ SST isotherm may limit the eastward dispersal of the tagged fish. Thus, there may be some degree of separation between the yellowfin tuna populations of the west and east Indian Ocean.

Results obtained from the RTTP-IO also describe fast and large-scale bigeye movements. The average monthly distance between tagging and recovery positions is 918 miles in the first year, with distances increasing slowly in subsequent years (Fonteneau and Hallier, 2015). For instance, bigeye released off Tanzania were subsequently recovered as far away as the subtropical Indian Ocean, eastern Indian Ocean and the southern and western coasts of South Africa (Hallier and Million, 2012). The reported fast and 
extensive movements of bigeye tuna in the Indian Ocean led to the assumption that its population is highly mobile, supporting the current assumption of a single stock for the Indian Ocean (IOTC, 2017a).

Conventional tagging studies, however, depend on tag-recapture efforts, and can be sensitive to the distribution of releases and assumptions related to the tagged population (e.g. random selection, independence and complete mixing) (Pollock and Pine, 2007; Berger et al., 2014). This may lead to biased results and data misinterpretation. Fonteneau and Hallier (2015) advised that current tagging programs targeting tropical tuna, may still not be adequate to estimate the potential stock mixing rates. For instance very few tags have been returned from the eastern Indian Ocean (Murua et al., 2015), which may reflect a lack movement from west to east, but more certainly, this is a consequence of poor reporting rates by longliners operating in the east Indian Ocean. Therefore, movement dynamics within the eastern Indian Ocean have not yet been adequately evaluated. Electronic tags may present a complementary platform to elucidate tropical tuna real movements. This technique proved to be useful in identifying population structure in other tuna species (Block et al., 2005). Finally, an accurate knowledge of tropical tuna movements in the Indian Ocean will be essential to establish management boundaries if different stocks are revealed.

\section{Conclusions and future research directions}

Since tropical tuna fisheries of the Indian Ocean play an important role in the three sustainability pillars (i.e., social, environmental and economic) of the region, there is an urgent need to advance our understanding of the resource and the fisheries to ensure a proper and sustainable management of these species (Asche et al., 2018). Scientific advice on tropical tuna of the Indian Ocean is based, among others, on the results of the stock assessment models. However, more accurate and comprehensive fishery data statistics, which cover all fisheries components, are needed to improve the monitoring and stock evaluation of these species which will, in turn, reduce the uncertainty of the assessment and improve the scientific advice for management. IOTC should, therefore, prioritize the capacity of the countries in the region to implement monitoring systems. This will allow to collect fishery statistics that contribute to the provision of the scientific advice for management of IOTC species. Strong monitoring systems, once implemented, will also ensure a better control mechanism to enforce any agreed management measure by IOTC (e.g. yellowfin catch limits and skipjack annual quota). Here, available information regarding Indian Ocean yellowfin, skipjack and bigeye tuna fisheries, life history and stock structure has been reviewed. This will 
help identify gaps in our knowledge that need to be filled to improve the assessment and management advice for these resources.

Firstly, there is, in general, a lack of information regarding life-history traits of skipjack, yellowfin and bigeye tuna at an oceanic scale in the Indian Ocean. Most studies are regionally limited, which impedes a global overview of the complex interaction between the environment and these species and makes it difficult to incorporate life-history parameters at the appropriate scale into stock assessment models. Studies that characterize fundamental life-history characteristics (e.g. growth and reproductive parameters) at ocean scale are needed to understand if differences stem from regional differences or just from different sampling strategies. Growth, mortality and reproduction are determinant factors for population productivity and, thus, key variables for stock assessment and management advice (Maunder et al., 2015). However, there are discrepancies regarding the growth and reproduction parameters of these key species in the Indian Ocean, which increases uncertainties in assessments of their status and advice for their management. Moreover, the fact that different studies calculate growth models based on fish from different size/age classes, caution the extrapolation of the results outside the range of the data. Therefore, future studies should ensure that sampling covers the full length-range of fish in the population to better inform stock assessment. Despite strong evidence of sexual-dimorphism in yellowfin and bigeye tuna growth (Eveson et al., 2015), which can lead to elevated sex-biased fishing mortality rates, this is not currently being considered in stock assessments due to a lack of the necessary data. Similarly, there is still not a consensus on spawning time and location of tropical tuna in the Indian Ocean, which is important to inform assumptions about total reproductive output. In order to move towards ecosystem-based fisheries management (EBFM), a better understanding of the habitat utilization and trophic relationships of the three tropical tuna in the Indian Ocean is also needed. Expanding the knowledge of vertical movements of these species would be useful to evaluate the species-specific and/or age class vulnerability to different fishing gears (e.g. purse-seine and longline) in the Indian Ocean and evaluate the impacts of FADs and potential utility of alternative management measures. Besides, a comprehensive approach that combines stomach content data, trophic markers (e.g. stable isotopes, mercury, lipid classes and fatty acids), and fish condition indices will allow delineation of trophic pathways for skipjack, yellowfin and bigeye tuna from the Indian Ocean. This information will be essential in understanding the effect of human induced pressures, such as fishing, climate change or the impact of the deployment of FADs, on these species. For example, skipjack tuna have 
and, hence, it is considered more resilient and less susceptible to overfishing than yellowfin and bigeye tuna. However, Worm and Tittensor (2011) reported that skipjack tuna has undergone distribution range reduction in the Indian Ocean, contrary to what occurred in the Pacific Ocean. Although is very difficult to establish the scale and ultimate cause of the observed range change in skipjack tuna, an understanding of habitat preferences, species interactions, climate change and variability and other factors can contribute to a better understanding of their population dynamics and resilience to fishing pressure.

Secondly, the current assumptions of single stocks for yellowfin, skipjack and bigeye tuna in the Indian Ocean, are based on the latest result of tag-recoveries from the RTTP-IO, which provide evidence of rapid and large-scale movements for these tuna species. However, tagging events do not represent the whole Indian Ocean. Moreover, the distances between tag release and recovery positions do not provide a full picture of the real movements of tagged tunas, which can, more effectively, be tracked by electronic tagging. Indeed, other methods should also be considered for realistic stock structure determination. With the advent of NGS methods, a comprehensive study of these tropical tuna genetic structures using genomewide highly informative SNP markers should be an important additional source of information to establish the underlying population structure. Natural markers, such as parasite tags or otolith microchemistry, can inform about the degree of connectivity over an ecological time scale (i.e. individual life span)and hence provide information on the environmental history experienced by individuals throughout different life stages. Therefore, they can contribute valuable insights of population structuring and highlight migration behaviours or population dynamics that might be sufficiently independent to guarantee spatially structured management. As each method provides information about stock structure at different spatial and/or temporal scales, the combination of different approaches has proved to be a powerful and reliable way to clarify unresolved questions related to stock structure (Welch et al., 2015; Pita et al., 2016; Izzo et al., 2017; Proctor et al., 2019) Thus, a holistic study that integrates results gained from several methods including different spatial and temporal scales, will be beneficial in defining appropriate units for the management of tropical tuna species in the Indian Ocean.

In summary, a broad-ranging collaborative program of research and data collection covering the complete distribution and life-history of the skipjack, yellowfin, and bigeye tuna in the Indian Ocean, should be carried out to improve stock assessment. These studies should be done together with the implementation of different and complementary stock delineation methods to establish the most realistic stock structure of the three tropical tuna species in the Indian Ocean, because species response to management decisions cannot 
be accurately predicted if the boundaries that characterise the stock are not correctly defined. Ultimately, an incorrect characterization of both life history parameters and stock structure perspectives may mislead the productivity and management of these globally important species. For example, if distinct stocks do exist, management measures based on the single stock assumption may lead to overexploitation and eventual collapse of less productive stocks. Therefore, an increased knowledge of these species' life-history characteristics and an accurate validation of stock structure of tropical tuna fisheries in the Indian Ocean will be essential to implement and enforce management strategies that ensure long-term sustainable fisheries.

\section{Acknowledgements}

Funding for this work was provide by the European Union (Grant number S12.697993) and the FAO/IOTC, within the framework of a collaborative project (GCP/INT/233/EC - Population structure of IOTC species in the Indian Ocean) between FAO/IOTC and CSIRO Oceans and Atmosphere, AZTI, Institut de Recherche pour le Développement (IRD), and Indonesia's Center for Fisheries Research (CFR). The views expressed herein can in no way be taken to reflect the official opinion of the European Union. The first author was funded by a research grant of the Department of Agriculture, Fisheries and Food Policy from the Basque Government (Convocatoria ayudas de formación a jóvenes investigadores y tecnólogos 2017). Authors thank to all people who at different stages helped to carry out the work, and specially to I. Zudaire, M. Grande, G. Merino, and I. Granado for technical clarifications. This paper is the contribution number 977 from AZTI, Marine Research, Basque Research and Technology Alliance (BRTA).

\section{References}

Adam, S., and Sibert, J. R. (2002). Population dynamics and movements of skipjack tuna (Katsuwonus pelamis) in the Maldivian fishery: analysis of tagging data from an advection-diffusion-reaction model. Aquat. Living Resour. 15, 13-23. doi:10.1016/S0990-7440(02)01155-5.

Agnew, D. J., Pearce, J., Pramod, G., Peatman, T., Watson, R., Beddington, J. R., and Pitcher, T. J. (2009). Estimating the worldwide extent of illegal fishing. PLoS One 4. doi:10.1371/journal.pone.0004570.

Ahusan, M., Nadheeh, I., and Adam, S. (2016). Length Distribution of Yellowfin Tuna from the Maldives Pole-and-line and Handline Tuna Fisheries. IOTC-2016-WPTT18-21.

Alvarado-Bremer, J. R., Stéquert, B., Robertson, N. W., and Ely, B. (1998). Genetic evidence for interoceanic subdivision of bigeye tuna (Thunnus obesus) populations. Mar. Biol. 132, 547-557. doi:10.1007/s002270050420.

Andrews, A. H., Pacicco, A., Allman, R., Falterman, B. J., Lang, E. T., and Golet, W. (2020). Age validation of yellowfin (Thunnus albacares) and bigeye (Thunnus obesus) tuna of the northwestern Atlantic Ocean. Can. J. Fish. Aquat. Sci. 77, 637-643. doi:637-643.

Anganuzzi, A. (2004). "Gathering data on unreported activities in Indian Ocean fishery," in Fish Piracy Combating Illegal, Unreported and Unregulated Fishing, ed. OECD, 147-155.

Appleyard, S. A., Ward, R. D., and Grewe, P. M. (2002). Genetic stock structure of bigeye tuna in the Indian Ocean using mitochondrial DNA and microsatellites. J. Fish Biol. 60, 667-670. doi:0.1006/jfbi.2002.1866.

Arai, T., Kotake, A., and Kayama, S. (2005). Movements and life history patterns of the skipjack tuna Katsuwonus pelamis in the western Pacific, as revealed by otolith Sr: Ca ratios. J. Mar. Biol. Assoc. United Kingdom 85, 1211-1216. doi:10.1017/s0025315405012336.

Arrizabalaga, H., Dufour, F., Kell, L., Merino, G., Ibaibarriaga, L., Chustd, G., Irigoien, X., Santiago, J., Murua, H., Fraile, I., Chifflet, M., Goikoetxea, N., Sagarminaga, Y., Aumont, O., Bopp, L., Herrera, 
M., Fromentin, J. M., and Bonhomeau, S. (2015). Global habitat preferences of commercially valuable tuna. Deep Sea Res. Part II Top. Stud. Oceanogr. 113, 102-112. doi:10.1016/j.dsr2.2014.07.001.

Artetxe-Arrate, I., Fraile, I., Crook, D., Zudaire, I., Arrizabalaga, H., Greig, A., and Murua, H. (2019). Otolith microchemistry: a useful tool for investigating stock structure of yellowfin tuna (Thunnus albacares) in the Indian Ocean. Mar. Freshw. Res. 70, 1708-1721. doi:10.1071/MF19067.

Asche, F., Garlock, T., Anderson, J., Bush, S., Smith, M., Anderson, C., Chu, J., Garrett, K. ., Lem, A., Lorenzen, K., Oglend, A., Tveteras, S., and Vannuccini, S. (2018). Three pillars of sustainability in fisheries. PNAS 115, 11221-11225. doi:10.1073/pnas.1807677115.

Bard, F., Kouamé, B., and Hervé, A. (2002). Schools of large yellowfin (Thunnus albacares) concentrated by foraging on a monospecific layer of Cubiceps pauciradiatus, observed in the eastern tropical Atlantic. ICCAT Coll Vol Sci Pap 54, 33-41.

Bard, F. X. (1984). Croissance de l'albacore (Thunnus albacares) Atlantique d'après les données de marquage. Rec. Doc. Sci. ICCAT 20, 104-116.

Barkley, R., Neill, W., and Gooding, R. (1978). Skipjack tuna, Katsuwonus pelamis, habitat based on temperature and oxygen requirements. Fish. Bull. 76, 653-662.

Barth, J., Damerau, M., Matschiner, M., Jentoft, S., and Hanel, R. (2017). Genomic differentiation and demographic histories of Atlantic and Indo-Pacific yellowfin tuna (Thunnus albacares) populations. Genome Biol. Evol. 9, 1084-1098. doi:10.1093/gbe/evx067.

Begg, G., Friedland, K., and Pearce, J. (1999). Stock identification and its role in stock assessment and fisheries management: an overview. Fish. Res. 43, 1-8. doi:10.1016/S0165-7836(99)00062-4.

Begg, G., and Waldman, J. (1999). An holistic approach to fish stock identification. Fish. Res. 43, 35-44. doi:10.1016/S0165-7836(99)00065-X.

Berger, A., McKechnie, S., Abascal, F., Kumasi, B., and Usu, T. (2014). Analysis of tagging data for the 2014 tropical tuna assessments: data quality rules, tagger effects, and reporting rates. WCPFC-SC102014/SA-IP-06. in (Majuro, Republic of the Marshall Islands).

Block, B., Teo, S., Walli, A., Boustany, A., Stokesbury, M., Farwell, C., Weng, K., Dewar, H., and Williams, T. (2005). Electronic tagging and population structure of Atlantic bluefin tuna. Nature 434, 1121-1127. doi:10.1038/nature03463.

Campana, S. (1999). Chemistry and composition of fish otoliths: pathways, mechanisms and applications. Mar. Ecol. Prog. Ser. 188, 263-297. doi:10.3354/meps188263.

Campana, S. E. (2005). “Otolith Elemental Composition as a Natural Marker of Fish Stocks,” in Stock Identification Methods . Applications in Fishery Science, eds. S. X. Cadrin, K. D. Friedland, and J. Waldman (Elsevier Academic Press), 227-245. doi:10.1016/B978-012154351-8/50013-7.

Carey, F., Teal, J., Kanwisher, J., Lawson, K. D., and Beckett, J. S. (1971). Warm-bodied fish. Am. Zool. 11, 137-143. doi:10.1093/icb/11.1.137.

Catalano, S., Whittington, I., and Donnellan, S. (2014). Parasites as biological tags to assess host population structure: guidelines, recent genetic advances and comments on a holistic approach. Int. J. Parasitol. Parasites Wildl. 3, 220-226. doi:10.1016/j.ijppaw.2013.11.001.

Ceo, M., Fagnani, S., Swan, J., Tamada, K., and Watanabe, H. (2012). Performance reviews by regional fishery bodies: Introduction, summaries, synthesis and best practices, Volume I: CCAMLR, CCSBT, ICCAT, IOTC, NAFO, NASCO, NEAFC,. Rome, Italy.

Chiang, H., Hsu, C., Wu, G., Chang, S., and Yang, H. (2008). Population structure of bigeye tuna (Thunnus obesus) in the Indian Ocean inferred from mitochondrial DNA. Fish. Res. 90, 305-312. doi:10.1016/j.fishres.2007.11.006.

Chow, S., Hazama, K., Nishida, T., Ikame, S., and Kurihara, S. (2000a). A preliminary genetic analysis on yellowfin tuna stock structure in the Indian Ocean using mitochondrial DNA variation. in IOTC Proceedings, 312-316. Available at: http://iotc.org/sites/default/files/documents/proceedings/2000/wptt/IOTC-2000-WPTT-11.pdf [Accessed May 3, 2017].

Chow, S., Okamoto, H., Miyabe, N., and Hiramatsu, K. (2000b). Genetic divergence between Atlantic and 
Indo-Pacific stocks of bigeye tuna (Thunnus obesus) and admixture around South Africa. Mol. Ecol. 9, 221-227. doi:10.1046/j.1365-294x.2000.00851.x.

Christ, H. J., White, R., Hood, L., Vianna, G. M. S., and Zeller, D. (2020). A Baseline for the Blue Economy: Catch and Effort History in the Republic of Seychelles' Domestic Fisheries. Front. Mar. Sci. 7. doi:10.3389/fmars.2020.00269.

Collette, B. B. (2017). Bluefin tuna science remains vague. Science (80-. ). 358, 879-880. doi:10.1126/science.aar3928.

Collette, B. B., Reeb, C., and Block, B. A. (2001). Systematics of the tunas and mackerels (Scombridae). Fish Physiol. 19, 1-33. doi:10.1016/S1546-5098(01)19002-3.

Conand, F., and Richards, W. J. (1982). Distribution of tuna larvae between Madagascar and the Equator, Indian Ocean. Biol. Oceanogr. 1, 321-336. doi:10.1080/01965581.1982.10749446.

Cullis-Suzuki, S., and Pauly, D. (2010). Failing the high seas: a global evaluation of regional fisheries management organizations. Mar. Policy 34, 1036-1042. doi:10.1016/j.marpol.2010.03.002.

Dagorn, L., Holland, K., Hallier, J., Taquet, M., Moreno, G., Sancho, G., Itano, D. G., Aumeeruddy, R., Girard, C., Million, J., and Fonteneau, A. (2006). Deep diving behavior observed in yellowfin tuna (Thunnus albacares). Aquat. Living Resour. 19, 85-88. doi:10.1051/alr:2006008.

Dammannagoda, S., Hurwood, D., and Mather, P. (2008). Evidence for fine geographical scale heterogeneity in gene frequencies in yellowfin tuna (Thunnus albacares) from the north Indian Ocean around Sri Lanka. Fish. Res. 90, 147-157. doi:10.1016/j.fishres.2007.10.006.

Dammannagoda, S., Hurwood, D., and Mather, P. (2011). Genetic analysis reveals two stocks of skipjack tuna (Katsuwonus pelamis) in the northwestern Indian Ocean. Can. J. Fish. Aquat. Sci. 68, 210-223. doi:10.1139/F10-136.

Díaz-Arce, N., Arrizabalaga, H., Murua, H., Irigoien, X., and Rodríguez-Ezpeleta, N. (2016). RAD-seq derived genome-wide nuclear markers resolve the phylogeny of tunas. Mol. Phylogenet. Evol. 102, 202-207. doi:10.1016/j.ympev.2016.06.002.

Dickson, K. (1995). Unique adaptations of the metabolic biochemistry of tunas and billfishes for life in the pelagic environment. Environ. Biol. Fishes 2, 65-97. doi:10.1007/BF00002352.

Dizon, A. E., Neill, W. H., and Magnuson, J. J. (1977). Rapid temperature compensation of volitional swimming speeds and lethal temperatures in tropical tunas (Scombridae). Environ. Biol. Fishes 2, 83-92. doi:10.1007/BF00001418.

Dortel, E., Sardenne, F., Bousquet, N., Rivot, E., and Million, J. (2015). An integrated Bayesian modeling approach for the growth of Indian Ocean yellowfin tuna. Fish. Res. 163, 69-84. doi:10.1016/j.fishres.2014.07.006.

Druon, J. N., Chassot, E., Murua, H., and Lopez, J. (2017). Skipjack Tuna Availability for Purse Seine Fisheries Is Driven by Suitable Feeding Habitat Dynamics in the Atlantic and Indian Oceans. Front. Mar. Sci. 4, 315. doi:10.3389/fmars.2017.00315.

Duffy, L., Kuhnert, P., Pethybridge, H., Young, J., Olson, R., Logan, J., Goñi, N., Romanov, E., Allain, V., Staudinger, M., Abecassis, M., Choy, C., Hobday, A., Simier, M., Galván-Magaña, F., Potier, M., and Ménard, F. (2017). Global trophic ecology of yellowfin, bigeye, and albacore tunas: Understanding predation on micronekton communities at ocean-basin scales. Deep Sea Res. Part II Top. Stud. Oceanogr. 140, 55-73. doi:10.1016/j.dsr2.2017.03.003.

Durand, J., Collet, A., Chow, S., Guinand, B., and Borsa, P. (2005). Nuclear and mitochondrial DNA markers indicate unidirectional gene flow of Indo-Pacific to Atlantic bigeye tuna (Thunnus obesus) populations, and their admixture off southern Africa. Mar. Biol. 147, 313-322. doi:10.1007/s00227005-1564-2.

Ely, B., Viñas, J., Alvarado-Bremer, J., Black, D., Lucas, L., Covello, K., Labrie, A., and Thelen, E. (2005). Consequences of the historical demography on the global population structure of two highly migratory cosmopolitan marine fishes: the yellowfin tuna (Thunnus albacares) and the skipjack tuna (Katsuwonus pelamis). BMC Evol. Biol. 5, 1-9. doi:10.1186/1471-2148-5-19.

Estes, J. A., Heithaus, M., McCauley, D. J., Rasher, D. B., and Worm, B. (2016). Megafaunal Impacts on Structure and Function of Ocean Ecosystems. Annu. Rev. Environ. Resour. 41, 83-116. doi:10.1146/annurev-environ-110615-085622. 
Evans, K., Langley, A., Clear, N. P., Williams, P., Patterson, T., Sibert, J., Hampton, J., and Gunn, J. S. (2008). Behaviour and habitat preferences of bigeye tuna (Thunnus obesus) and their influence on longline fishery catches in the western Coral Sea. Can. J. Fish. Aquat. Sci. 65, 2427-2443. doi:10.1139/F08-148.

Eveson, J., Million, J., Sardenne, F., and Croizier, G. L. (2015). Estimating growth of tropical tunas in the Indian Ocean using tag-recapture data and otolith-based age estimates. Fish. Res. 163, 58-68. doi:10.1016/j.fishres.2014.05.016.

Eveson, J., Million, J., Sardenne, F., and Le Croizier, G. (2012). Updated growth estimates for Skipjack, Yellowfin and Bigeye tuna in the Indian Ocean using the most recent tag-recapture and otolith data. IOTC-2012-WPTT14-23, 1-57.

FAO (2016). The State of World Fisheries and Aquaculture 2016. Contributing to food security and nutrition for all. Rome.

FAO (2018). The State of World Fisheries and Aquaculture 2018- Meeting the sustainable development goals. Rome.

Farley, J., Clear, N., Leroy, B., Davis, T., and McPherson, G. (2006). Age, growth and preliminary estimates of maturity of bigeye tuna, Thunnus obesus, in theAustralian region. Mar. Freshw. Res. 57, 713-724. doi:10.1071/MF05255.

Flynn, A., and Paxton, J. (2013). Spawning aggregation of the lanternfish Diaphus danae (family Myctophidae) in the north-western Coral Sea and associations with tuna aggregations. Mar. Freshw. Res. 63, 1255-1271.

Fonteneau, A. (1980). La croissance de l'albacore de l'Atlantique. Est. Rec. Doc. Sci. ICCAT 9, 152-168.

Fonteneau, A. (2010). Atlas des pêcheries thonières de l'océan Indien/Atlas of Indian Ocean tuna fisheries. IRD Ed., 191.

Fonteneau, A. (2014). On the movements and stock structure of skipjack (Katsuwonus pelamis) in the Indian ocean. IOTC-2014-WPTT16-36, 1-16.

Fonteneau, A., and Hallier, J. P. (2015). Fifty years of dart tag recoveries for tropical tuna: A global comparison of results for the western Pacific, eastern Pacific, Atlantic,and Indian Oceans. Fish. Res. 163, 7-22. doi:10.1016/j.fishres.2014.03.022.

Fu, D. (2019). Preliminary Indian Ocean bigeye tuna stock assessment 1950-2018 (stock synthesis). IOTC2019-WPTT21-61.

Fu, D., Merino, G., Langley, A., and Ijurco, A. (2018). Preliminary Indian Ocean yellowfin tuna stock assessment 1950-2017 (stock synthesis). IOTC-2018-WPTT20-33. IOTC-2018-WPTT20-33.

Fujino, K., Sassaki, K., and Okumura, S. (1981). Genetic diversity of skipjack tuna in the Atlantic, Indian and Pacific Oceans. Bull. Japanese Soc. Sci. Fish 47, 215-222.

Galland, G., Rogers, A., and Nickson, A. (2016). Netting Billions: A Global Valuation of Tuna.

Glaser, S. M., Roberts, P. M., and Hurlburt, K. J. (2019). Foreign Illegal, Unreported, and Unregulated Fishing in Somali Waters Perpetuates Conflict. Front. Mar. Sci. 6. doi:10.3389/fmars.2019.00704.

Gonzalez, E., Beerli, P., and Zardoya, R. (2008). Genetic structuring and migration patterns of Atlantic bigeye tuna, Thunnus obesus (Lowe, 1839). BMC Evol. Biol. 8. doi:10.1186/1471-2148-8-252.

Goujon, M., and Majkowski, C. (2010). Biological characteristics of tuna. FAO Fish. Aquac. Dep. Available at: http://www.fao.org/fishery/ [Accessed March 7, 2018].

Govindraj, M. E., Premchand, J., Unnikrishnan, N., Thomas, J., and Somvanshi, V. . (2000). Oceanic tuna resources in the north west region of Indian EEZ. Bull. Fish. Surv. India 27, 20.

Graham, B., Grubbs, D., Holland, K., and Popp, B. (2007). A rapid ontogenetic shift in the diet of juvenile yellowfin tuna from Hawaii. Mar. Biol. 150, 647-658. doi:10.1007/s00227-006-0360-y.

Graham, J. (1975). Heat exchange in the yellowfin tuna, Thunnus albacares, and skipjack tuna, Katsuwonus pelamis, and the adaptive significance of elevated body temperatures in scombrid fishes. Fish. Bull. 73, 219-229.

Graham, J. B., and Dickson, K. A. (2004). Tuna comparative physiology. J. Exp. Biol. 207, 4015-4024. 
doi:10.1242/jeb.01267.

Grande, M., Murua, H., Zudaire, I., Arsenault-Pernet, E. J., Pernet, F., and Bodin, N. (2016). Energy allocation strategy of skipjack tuna Katsuwonus pelamis during their reproductive cycle. J. Fish Biol. 89, 2434-2448. doi:10.1111/jfb.13125.

Grande, M., Murua, H., Zudaire, I., Goni, N., and Bodin, N. (2014). Reproductive timing and reproductive capacity of the Skipjack Tuna (Katsuwonus pelamis) in the western Indian Ocean. Fish. Res. 156, 14-22. doi:10.1016/j.fishres.2014.04.011.

Grande, M., Murua, H., Zudaire, I., and Korta, M. (2010). Spawning activity and batch fecundity of skipjack, Katsuwonus pelamis, in the Western Indian Ocean. IOTC-2010- WPTT-47.

Grande, M., Murua, H., Zudaire, I., and Korta, M. (2012). Oocyte development and fecundity type of the skipjack, Katsuwonus pelamis, in the Western Indian Ocean. J. Sea Res. 73, 117-125. doi:10.1016/j.seares.2012.06.008.

Graves, J. E., Ferris, S. D., and Dizon, A. E. (1984). Close genetic similarity of Atlantic and Pacific skipjack tuna (Katsuwonus pelamis) demonstrated with restriction endonuclease analysis of mitochondrial DNA. Mar. Biol. 79, 315-319. doi:10.1007/BF00393264.

Grewe, P., Feutry, P., Hill, P., Gunasekera, R., Schaefer, K., Itano, D. G., Fuller, D., Foster, S., and Davies, C. (2015). Evidence of discrete yellowfin tuna (Thunnus albacares) populations demands rethink of management for this globally important resource. Nat. Sci. Reports 5, 16916. doi:10.1038/srep16916.

Hallier, J., and Gaertner, D. (2008). Drifting fish aggregation devices could act as an ecological trap for tropical tuna species. Mar. Ecol. Prog. Ser. 353, 255-264. doi:10.3354/meps07180.

Hallier, J., and Million, J. (2012). The Indian Ocean Tuna Tagging Programme. in Indian Ocean Tuna Tagging Symposium (Mauritius), 1-36.

Han, W., Vialard, J., McPhaden, M. J., Lee, T., Masumoto, Y., Feng, M., and de Ruijter, W. P. M. (2014). Indian Ocean Decadal Variability: A Review. Bull. Am. Meteorol. Soc. 95, 1679-1703. doi:10.1175/BAMS-D-13-00028.1.

Hassani, S., and Stéquert, B. (1991). Sexual maturity spawning and fecundity of the yellowfin tuna (Thunnus albacares) of the Western Indian Ocean. Indo-Pacific Tuna Manag. Prog. Coll. Work. Doc. 4, 1-107.

Heithaus, M. R., Frid, A., Wirsing, A. J., and Worm, B. (2008). Predicting ecological consequences of marine top predator declines. Trends Ecol. Evol. 23, 202-210. doi:10.1016/j.tree.2008.01.003.

Hoyle, S. D. (2018). Indian Ocean tropical tuna regional scaling factors that allow for seasonality and cell areas. IOTC-2018-WPM09-13.

Hoyle, S. D., and Langley, A. (2020). Scaling factors for multi-region stock assessments, with an application to Indian Ocean tropical tunas. Fish. Res. 228, 105586. doi:10.1016/j.fishres.2020.105586.

Hunter, J. R., Macewicz, B. J., and Sibert, J. R. (1986). The spawning frequency of skipjack tuna, Katsuwonus pelamis, from the south Pacific. Fish. Bull. 84, 895-903.

Hutchings, J. (2000). Collapse and recovery of marine fishes. Nature 406, 882-885. doi:10.1038/35022565.

IOTC (2017a). Bigeye Tuna Supporting Information. Status Summ. Species Tuna Tuna-Like Species Under IOTC Mandate, as well as Other Species Impacted by IOTC Fish. Available at: http://www.iotc.org/science/status-summary-species-tuna-and-tuna-species-under-iotc-mandatewell-other-species-impacted-iotc [Accessed February 3, 2017].

IOTC (2017b). Skipjack Tuna Supporting Information. Status Summ. Species Tuna Tuna-Like Species Under IOTC Mandate, as well as Other Species Impacted by IOTC Fish. Available at: http://www.iotc.org/science/status-summary-species-tuna-and-tuna-species-under-iotc-mandatewell-other-species-impacted-iotc [Accessed May 15, 2017].

IOTC (2017c). Yellowfin Tuna Supporting Information. Status Summ. Species Tuna Tuna-Like Species Under IOTC Mandate, as well as Other Species Impacted by IOTC Fish. Available at: http://www.iotc.org/documents/status-indian-ocean-yellowfin-tuna-yft-thunnus-albacares-resource [Accessed February 3, 2017]. 
IOTC (2019a). Nominal catch by species and gear, by vessel flag reporting country. IOTC-2019DATASETS-NCDB. Available at: https://www.iotc.org/data/datasets/latest/NC [Accessed January 17, 2020].

IOTC (2019b). Report of the 22nd session of the IOTC scientific committee. IOTC-2019-SC22-R. Available at: https://iotc.org/documents/SC/22/RE.

IOTC (2019c). Report on IOTC data collection and statistics. IOTC-2019-WPDCS15-07. Available at: https://iotc.org/documents/report-15th-session-iotc-working-party-data-collection-and-statistics-0.

ISSF (2020). Status of the world fisheries for tuna. Mar. 2020. ISSF Technical Report 2020-12. Washington, D.C., USA.

Izzo, C., Ward, T., Ivey, A., Suthers, I., and Stewart, J. (2017). Integrated approach to determining stock structure: implications for fisheries management of sardine, Sardinops sagax, in Australian waters. Rev. Fish Biol. Fish. 27, 267-284. doi:10.1007/s11160-017-9468-z.

Jaquemet, S., Potier, M., and Ménard, F. (2011). Do drifting and anchored Fish Aggregating Devices (FADs) similarly influence tuna feeding habits? A case study from the western Indian Ocean. Fish. Res. 107, 283-290. doi:10.1016/j.fishres.2010.11.011.

Jatmiko, I., Zedta, R. R., Agustina, M., and Setyadji, B. (2019). Genetic Diversity and Demography of Skipjack Tuna (Katsuwonus pelamis) In Southern and Western Part of Indonesian Waters. ILMU Kelaut. Indones. J. Mar. Sci. 24, ILMU KELAUTAN: Indonesian Journal of Marine Scienc. doi:10.14710/ik.ijms.24.2.61-68.

Jennings, S., Reynolds, J. D., and Mills, S. C. (1998). Life history correlates of responses to fisheries exploitation. R. Soc. London B Biol. Sci. 265, 333-339. doi:10.1098/rspb.1998.0300.

John, M. E. (1995). Studies on Yellowfin tuna, Thunnus albacares (Bonnaterre, 1788) in the Indian Seas. Dr. Diss. Univ. Mumbai, 258.

John, M. E., Neelakandan, M., Sivaji, V., Premchand, Parasuraman, P.S. Sanjeevan, M. ., and Sivaraj, P. (1998). Some aspects on the reproductive biology of Yellowfin tuna (Thunnus albacres) in the Bay of Bengal. Bull. Fish. Surv. India 26, 42-50.

Joseph, J. (1963). Fecundity of yellowfin tuna (Thunnus albacares) and skipjack (Katsuwonus pelamis) from the Pacific Ocean. Inter-Am. Trop. Tuna Comm. Bull. 7, 257-292.

Juan-Jordá, M. J., Mosqueira, I., Freire, J., and Dulvy, N. K. (2013). Life in 3-D: life history strategies in tunas, mackerels and bonitos. Rev. Fish Biol. Fish. 23, 135-155. doi:10.1007/s11160-012-9284-4.

Juan-Jordá, M. J., Murua, H., Arrizabalaga, H., Dulvy, N. K., and Restrepo, V. (2017). Report card on ecosystem-based fisheries management in tuna regional fisheries management organizations. Fish Fish. 19, 321-339. doi:10.1111/faf.12256.

Jury, M., McClanahan, T., and Maina, J. (2010). West Indian Ocean variability and East African fish catch. Mar. Environ. Res. 70, 162-170. doi:10.1016/j.marenvres.2010.04.006.

Kaji, T., Tanaka, M., Oka, M., Takeuchi, H., Ohsumi, S., Teruya, K., and Hirokawa, J. (1999). Growth and Morphological Development of Laboratory-Reared Yellowfin Tuna Thunnus albacares Larvae and Early Juveniles, with Special Emphasis on the Digestive System. Fish. Sci. 65, 700-707.

Kaplan, D., Chassot, E., Amandé, J., Dueri, S., Herve, D., Dagorn, L., and Fonteneau, A. (2014). Spatial management of Indian Ocean tropical tuna fisheries: potential and perspectives. ICES J. Mar. Sci. 71, 1728-1749. doi:10.1093/icesjms/fst233.

Kayama, S., Tanabe, T., Ogura, M., Okamoto, H., and Watanabe, Y. (2004). Daily age of skipjack tuna, Katsuwonus pelamis (Linnaeus), in the eastern Indian Ocean. IOTC-2004-WPTT-03.

Kerr, L., Hintzen, N., and Cadrin, S. (2016). Lessons learned from practical approaches to reconcile mismatches between biological population structure and stock units of marine fish. ICES J. Mar. Sci. doi:10.1093/icesjms/fsw188.

Kim, Y., Delgado, D. I., Cano, I. A., and Sawada, Y. (2015). Effect of temperature and salinity on hatching and larval survival of yellowfin tuna Thunnus albacares. Fish. Sci. 81, 891-897. doi:10.1007/s12562015-0901-8.

Kimura, S., Nakata, H., Margulies, D., Suter, J., and Hunt, S. (2004). Effect of oceanic turbulence on the 
survival of yellowfin tuna larvae. Bull. Japanese Soc. Sci. Fish. 70, 175-178.

King, J. R., and McFarlane, G. A. (2003). Marine fish life history strategies: applications to fishery management. Fish. Manag. Ecol. 10, 249-264. doi:10.1046/j.1365-2400.2003.00359.x.

Kitagawa, T., Ishimura, T., Uozato, R., Shirai, K., Amano, Y., Shinoda, A., Otake, T., Tsunogai, U., and Kimura, S. (2013). Otolith $\delta 180$ of Pacific bluefin tuna Thunnus orientalis as an indicator of ambient water temperature. Mar. Ecol. Prog. Ser. 481, 199-209. doi:10.3354/meps10202.

Kitchens, L. (2017). Origin and Population Connectivity of Yellowfin Tuna (Thunnus albacares) in the Atlantic Ocean. Dr. Diss. Texas A M Univ.

Kolody, D., and Adam, S. (2011). Maldives Skipjack Pole and Line Fishery Catch Rate Standardization 2004-2010. IOTC-2011-WPDCS08-INF01.

Kolody, D., and Hoyle, S. (2013). Evaluation of Tag Mixing Assumptions for Skipjack, Yellowfin and Bigeye Tuna Stock Assessments in the Western Pacific and Indian Oceans. WCPFC-SC9-2013/SAIP-11.

Kornilova, G. (1980). Feeding of yellowfin tuna, Thunnus albacares, and bigeye tuna Thunnus obesus, in the equatorial zone of the Indian Ocean. J. Ichthyol. 20, 111-119.

Korsmeyer, K. ., and Dewar, H. (2001). Tuna metabolism and energetics. Fish Physiol. 19, 35-78. doi:10.1016/S1546-5098(01)19003-5.

Koya, K., Joshi, K., and Abdussamad, E. (2012). Fishery, biology and stock structure of skipjack tuna, Katsuwonus pelamis (Linnaeus, 1758) exploited from Indian waters. Indian J. Fish. 59, 39-47. Available at: http://eprints.cmfri.org.in/8988/ [Accessed May 15, 2017].

Kumar, G., and Kocour, M. (2015). Population Genetic Structure of Tunas Inferred from Molecular Markers: A Review. Rev. Fish. Sci. Aquac. 23, 72-89. doi:10.1080/23308249.2015.1024826.

Kume, S., Morita, Y., and Ogi, T. (1971). Stock structure of the Indian bigeye tuna, Thunnus obesus (Lowe), on the basis of distribution, size composition and sexual maturity. Bull. Far Seas Fish. Res. Lab 4, 141-164.

Kunal, S., Kumar, G., Menezes, M., and Meena, R. (2013). Mitochondrial DNA analysis reveals three stocks of yellowfin tuna Thunnus albacares (Bonnaterre, 1788) in Indian waters. Conserv. Genet. 14, 205-213. doi:10.1007/s10592-013-0445-3.

Kurogane, K., and Hiyama, Y. (1958). Morphometric comparison of the yellowfin tuna from six grounds in the Indian Ocean. Bull. Japanese Soc. Sci. Fish 24.

Langley, A. (2016). Stock assessment of bigeye tuna in the Indian Ocean for 2016-model development and evaluation. IOTC-2016-WPTT18-20.

Langley, A., Hampton, J., Herrera, M., and Million, J. (2008). Preliminary stock assessment of yellowfin tuna in the Indian Ocean using MULTIFAN-CL. IOTC-2008-WPTT-10.

Langley, A., and Million, J. (2012). Determining an appropriate tag mixing period for the Indian Ocean yellowfin tuna stock assessment. IOTC-2012-WPTT14-31.

Le Manach, F., Gough, C., Harris, A., Humber, F., Harper, S., and Zeller, D. (2016). "Madagascar," in Global atlas of marine fisheries: a critical appraisal of catches ad ecosystem impacts, eds. D. Pauly and D. Zeller (Washington, D.C., USA: Island Press), 322.

Lee, P.-F., Chen, I.-C., and Tzeng, W.-N. (2005). Spatial and Temporal Distribution Patterns of Bigeye Tuna (Thunnus obesus) in the Indian Ocean. Zool. Stud. 44, 260-270.

Lestari, P., Lester, R., and Proctor, C. (2017). Parasites as potential stock markers for tuna in Indonesian Waters. Indones. Fish. Res. J. 23, 23-28.

Li, P., Chen, J. T., and Zhu, G. P. (2010). Biological characteristics of bigeye tuna (Thunnus obesus) in southern and central Indian Ocean. Mar. Coast. Fish. 32, 283-289.

Macfadyen, G. (2016). Estimate of the global sales values from tuna fisheries_Phase 3 Report. Windrush, Warborne Lane, Portmore, Lymington, Hampshire SO41 5RJ, UK.

Majkowski, C., Arrizabalaga, H., and Murua, H. (2011). “Tuna and tuna-like species," in Review of the state of world marine fishery resources (Rome, Italy), 227-244. 
Majid, A., and Ahmed, M. (1991). Status of yellowfin tuna (Thuunus albacares) fishery in Pakistan. IPTP Coll. Vol. Work. Doc., 34.

Maldeniya, R. (1996). Food consumption of yellowfin tuna, Thunnus albacares, in Sri Lankan waters. Environ. Biol. Fishes 47, 101-107. doi:10.1007/BF00002384.

Marsac., F. (2017). "The Seychelles Tuna fishery and climate change," in Climate change impacts on fisheries and aquaculture, eds. M. Perez-Ramirez and B. Phillips (Wiley Blackwell), 523-568.

Marsac, F. (1991). Growth of Indian Ocean yellowfin tuna estimated from size frequencies data collected on French purse seiners. TWS/91/17, IPTP, Coll. Vol. Work. Doc. 6, 34-39.

Marsac, F., Fonteneau, A., and Michaud, P. (2014). L'or bleu des Seychelles. Histoire de la pêche industrielle au thon dans l'océan Indien. IRD Ed., 269.

Marsac, F., Fonteneau, E., and Ménard, F. (2000). "Drifting FADs used in tuna fisheries: an ecological trap?," in Pêche thonière et dispositifs de concentration de poissons, eds. J. Le Gall, P. Cayré, and M. Taquet (Ed. Ifremer, Actes Colloq.), 537-552.

Marsac, F., and Le Blanc, J. L. (1998). Interannual and ENSO-associated variability of the coupled oceanatmosphere system with possible impacts on the yellowfin tuna fisheries of the Indian and Atlantic oceans. in ICCAT Tuna Symposium. Coll. Vol. Sci. Pap., ed. J. S. Beckett, L(1):345-377.

Marsac, F., and Le Blanc, J. L. (1999). Oceanographic changes during the 1997-1998 El Niño in the Indian Ocean and their impact on the purse seine fishery. 1st session of the IOTC working party on tropical tunas, Mahe, Seychelles, 4-8/09/99. WPTT/99/03. IOTC Proc. 2, 147-157.

Martinez, P., Gonzalez, E., Castilho, R., and Zardoya, R. (2006). Genetic diversity and historical demography of Atlantic bigeye tuna (Thunnus obesus). Mol. Phylogenet. Evol. 39, 404-416. doi:10.1016/j.ympev.2005.07.022.

Matsumoto, W., Skillman, R., and Dizon, A. (1984). Synopsis of biological data on skipjack tuna, Katsuwonus pelamis. FAO Fish. Synopsis 45, 1-92.

Maunder, M., Crone, P., Valero, J., and Semmens, B. (2015). Growth: theory, estimation, and application in fishery stock assessment models. in CAPAM Workshop Series Report 2 (La Jolla, California).

McCluney, J. K., Anderson, C., and Anderson, J. (2019). The fishery performance indicators for global tuna fisheries. Nat. Commun. 10, 1641. doi:10.1038/s41467-019-09466-6.

Ménard, F., Labrune, C., Shin, Y.-J., Asine, A.-S., and Bard, F. (2006). Opportunistic predation in tuna: a size-based approach. Mar. Ecol. Prog. Ser. 323, 223-231. doi:10.3354/ meps323223.

Ménard, F., Lorrain, A., Potier, M., and Marsac, F. (2007a). Isotopic evidence of distinct feeding ecologies and movement patterns in two migratory predators (yellowfin tuna and swordfish) of the western Indian Ocean. Mar. Biol. 153, 141-152. doi:10.1007/s00227-007-0789-7.

Ménard, F., Marsac, F., Bellier, E., and Cazelles, B. (2007b). Climatic oscillations and tuna catch rates in the Indian Ocean: a wavelet approach to time series analysis. Fish. Oceanogr. 16, 95-104.

Menezes, M., Kumar, G., and Kunal, S. (2012). Population genetic structure of skipjack tuna Katsuwonus pelamis from the Indian coast using sequence analysis of the mitochondrial DNA D-loop region. $J$. Fish Biol. 80, 2198-2212. doi:10.1111/j.1095-8649.2012.03270.x.

Menezes, M. R., Ikeda, M., and Taniguchi, N. (2006). Genetic variation in skipjack tuna Katsuwonus pelamis(L.) using PCR-RFLP analysis of the mitochondrial DNA D-loop region. J. Fish Biol. 68, 156-161. doi:10.1111/j.0022-1112.2006.00993.x.

Menezes, M. R., Noguchi, D., Nakajima, M., and Taniguchi, N. (2008). Microsatellite development and survey of genetic variation in skipjack tuna Katsuwonus pelamis. J. Fish Biol. 73, 463-473. doi:10.1111/j.1095-8649.2008.01912.x.

Miller, K. I., Nadheeh, I., Riyaz Jauharee, A., Charles Anderson, R., and Shiham Adam, M. (2017). Bycatch in the Maldivian pole-and-line tuna fishery. PLoS One 12. doi:10.1371/journal.pone.0177391.

Moore, B., Lestari, P., Cutmore, S., Proctor, C., and Lester, R. (2019). Movement of juvenile tuna deduced from parasite data. ICES J. Mar. Sci. doi:10.1093/icesjms/fsz022.

Morgan, M. J., Murua, H., Kraus, G., Lambert, Y., Marteinsdóttir, G., Marshall, C. T., O’Brien, L., and Tomkiewicz, J. (2009). The evaluation of reference points and stock productivity in the context of 
alternative indices of stock reproductive potential. Can. J. Fish. Aquat. Sci. 66, 404-414. doi:10.1139/F09-009.

Morita, Y., and Koto, T. (1970). Some consideration on the population structure of yellowfin tuna in the Indian Ocean based on the longline fishery data. Bull. Far. Seas Fish. Res. Lab 4, 125-140.

Mullins, R., McKeown, N., Sauer, W., and Shaw, P. (2018). Genomic analysis reveals multiple mismatches between biological and management units in yellowfin tuna (Thunnus albacares). ICES J. Mar. Sci. fsy102. doi:10.1093/icesjms/fsy 102.

Murua, H., Eveson, J., and Marsac, F. (2015). The Indian Ocean Tuna Tagging Programme: Building better science for more sustainability. Fish. Res. 163, 1-6. doi:10.1016/j.fishres.2014.07.001.

Murua, H., Rodriguez-Marin, E., Neilson, J. D., Farley, J. H., and Juan-Jordá, M. J. (2017). Fast versus slow growing tuna species: age, growth, and implications for population dynamics and fisheries management. Rev. Fish Biol. Fish., 1-41. doi:10.1007/s11160-017-9474-1.

Nishida, T. (1992). Considerations of stock structure of yellowfin tuna (Thunnus albacares) in the Indian Ocean based on fishery data. Fish. Oceanogr. 1, 143-152. doi:10.1111/j.1365-2419.1992.tb00033.x.

Nishida, T., Chow, S., and Grewe, P. (1998). Review and research plan on the stock structure of yellowfin tuna (Thunnus albacares) and bigeye tuna (Thunnus obesus) in the Indian Ocean. IOTC Proceedings, 7th Expert Consult. Indian Ocean Tunas, 230-236. Available at: http://www.oceandocs.org/handle/1834/59 [Accessed May 2, 2017].

Nishida, T., Chow, S., Ikame, S., and Kurihara, S. (2001). RFLP analysis on single copy nuclear gene loci in yellowfin tuna (Thunnus albacares) to examine the genetic differentiation between the western and eastern. IOTC Proc. 4, 437-441. Available at: http://iotc.org/sites/default/files/documents/proceedings/2001/wptt/IOTC-2001-WPTT-16.pdf [Accessed May 3, 2017].

Nootmorn, P. (2004). Reproductive biology of Bigeye tuna in the eastern Indian Ocean. IOTC Proc. 7, 15.

Nootmorn, P., Yakoh, A., and Kawises, K. (2005). Reproductive biology of yellowfin tuna in the Eastern Indian Ocean. IOTC-2005-WPTT-14, 379-385.

Nugraha, B., Baskoro, M. S., Pane, A. B., and Nugroho, E. (2010). Genetic Diversity of bigeye tuna (Thunnus obesus) based on mtDNA analysis with the PCR-RFLP technique. Indones. Fish. Res. J. 16, 25-32.

Olivier, L. (2002). Study of the growth of Yellowfin tuna (Thunnus albacares) in the Western Indian Ocean based on length frequency data. IOTC Proc. 5, 316-327. Available at: http://wws.iotc.org/sites/default/files/documents/proceedings/2002/wptt/IOTC-2002-WPTT-18.pdf [Accessed May 3, 2017].

Olson, R. J., Young, J. W., Ménard, F., Potier, M., Allain, V., Goñi, N., Logan, J., and Galván-Magaña, F. (2016). Bioenergetics, trophic ecology, and niche separation of tunas. Adv. Mar. Biol. 74, 199-344. doi:10.1016/bs.amb.2016.06.002.

Pauly, D. ., and Zeller, D. (2016). Catch reconstructions reveal that global marine fisheries catches are higher than reported and declining. Nat. Commun. 7, 10244. doi:10.1038/ncomms10244.

Pauly, D., Alder, J., Bennet, E., Christensen, V., Tyedmers, P., and Watson, R. (2003). The future of fisheries. Science (80-. ). 302, 1359-1361. doi:10.1126/science.1088667.

Pecoraro, C., Babbucci, M., Franch, R., Rico, C., Papetti, C., Chassot, E., Bodin, N., Cariani, A., Bargelloni, L., and Tinti, F. (2018). The population genomics of yellowfin tuna (Thunnus albacares) at global geographic scale challenges current stock delineation. Sci. Rep. 8, 13890. doi:10.1038/s41598-01832331-3.

Pecoraro, C., Zudaire, I., Bodin, N., Murua, H., Taconet, P., Díaz-Jaimes, P., Cariani, A., Tinti, F., and Chassot, E. (2016). Putting all the pieces together: integrating current knowledge of the biology, ecology, fisheries status, stock structure and management of yellowfin tuna (Thunnus albacares). Rev. Fish Biol. Fish. 27, 811-841. doi:10.1007/s11160-016-9460-z.

Pillai, P., and Silas, E. (1979). Distribution and biology of the Skipjack tuna Katsuwonus pelamis (Linnaeus) taken by the longline fishery in the Indian Ocean. J. Mar. Biol. Assoc. 21, 147-170. Available at: http://eprints.cmfri.org.in/1505/ [Accessed May 16, 2017]. 
Pita, A., Casey, J., Hawkins, S. J., Villarreal, M. R., Gutiérrez, M. J., Cabral, H., Carocci, F., Abaunza, P., Pascual, S., and Presa, P. (2016). Conceptual and practical advances in fish stock delineation. Fish. Res. 173, 185-193. doi:10.1016/j.fishres.2015.10.029.

Pollock, K. H., and Pine, W. E. (2007). The design and analysis of field studies to estimate catch-andrelease mortality. Fish. Manag. 14, 1-8.

Pons, M., Melnychuk, M. C., and Hilborn, R. (2017). Management effectiveness of large pelagic fisheries in the high seas. Fish Fish. 00, 1-11. doi:10.1111/faf.12253.

Potier, M., Lucas, V., Marsac., F., Ménard, F., and Sabatié, R. (2002). On-going research activities on trophic ecology of tuna in equatorial ecosystems of Indian Ocean. IOTC Proc. 5, 368-374.

Potier, M., Marsac, F., Cherel, Y., Lucas, V., and Sabatié, R. (2007). Forage fauna in the diet of three large pelagic fishes (lancetfish, swordfish and yellowfin tuna) in the western equatorial Indian Ocean. Fish. Res. 83, 60-72. doi:10.1016/j.fishres.2006.08.020.

Potier, M., Marsac, F., Lucas, V., Sabatié, R., Hallier, J., and Ménard, F. (2004). Feeding Partitioning among Tuna Taken in Surface and Mid-water Layers: The Case of Yellowfin (Thunnus albacares) and Bigeye (T. obesus) in the Western Tropical Indian Ocean. West. Indian Ocean J. Mar. Sci. 3, 5162.

Potier, M., Romanov, E., Cherel, Y., Sabatié, R., Zamorov, V., and Ménard, F. (2008). Spatial distribution of Cubiceps pauciradiatus (Perciformes: Nomeidae) in the tropical Indian Ocean and its importance in the diet of large pelagic fishes. Aquat. Living Resour. 21, 123-134. doi:10.1051/alr:2008026.

Proctor, C. H., Lester, R. J. G., Clear, N. P., Grewe, P. M., Moore, B. R., Eveson, J. P., Lestari, P., Wujdi, A., Taufik, M., Wudianto, Lansdell, M. J., Hill, P. L., Dietz, C., Thompson, J. M., Cutmore, S. C., Foster, S. D., Gosselin, T., and Davies, C. R. (2019). Population structure of yellowfin tuna (Thunnus albacares) and bigeye tuna (T. obesus) in the Indonesian region. Final Report as output of ACIAR Project FIS/2009/059. Camberra.

Qiu, F., Kitchen, A., Beerli, P., and Miyamoto, M. (2013). A possible explanation for the population size discrepancy in tuna (genus Thunnus) estimated from mitochondrial DNA and microsatellite data. Mol. Phylogenet. Evol. 66, 463-468. doi:10.1016/j.ympev.2012.05.002.

Reglero, P., Tittensor, D., Álvarez-Berastegui, D., Aparicio-González, A., and Worm, B. (2014). Worldwide distributions of tuna larvae: revisiting hypotheses on environmental requirements for spawning habitats. Mar. Ecol. Prog. Ser. 501, 207-224. doi:10.3354/meps10666.

Reygondeau, G., Maury, O., and Beaugrand, G. (2012). Biogeography of tuna and billfish communities. $J$. Biogeogr. 39, 114-129. doi:10.1111/j.1365-2699.2011.02582.x.

Rodríguez-Ezpeleta, N., Díaz-Arce, N., Walter, J. F., Richardson, D. E., Rooker, J. R., Nøttestad, L., Hanke, A. R., Franks, J. S., Deguara, S., Lauretta, M. V., Addis, P., Varela, J. L., Fraile, I., Goñi, N., Abid, N., Alemany, F., Oray, I. K., Quattro, J. M., Sow, F. N., et al. (2019). Determining natal origin for improved management of Atlantic bluefin tuna. Front. Ecol. Environ. 17, 439-444. doi:10.1002/fee.2090.

Roger, C. (1994). Relationships among yellowfin and skipjack tuna, their prey-fish and plankton in the tropical western Indian Ocean. Fish. Oceanogr. 3, 133-141. doi:10.1111/j.13652419.1994.tb00055.x.

Romanov, E., Potier, M., Zamorov, V., and Ménard, F. (2009). The swimming crab Charybdis smithii: distribution, biology and trophic role in the pelagic ecosystem of the western Indian Ocean. Mar. Biol. 156, 1089-1107. doi:10.1007/s00227-009-1151-z.

Rooker, J. R., David Wells, R. J., Itano, D. G., Thorrold, S. R., and Lee, J. M. (2016). Natal origin and population connectivity of bigeye and yellowfin tuna in the Pacific Ocean. Fish. Oceanogr. 25, 277291. doi:10.1111/fog.12154.

Saji, N. H., Goswami, B. N., Vinayachandran, P. N., and Yamagata, T. (1999). A dipole mode in the tropical Indian Ocean. Nature 401, 360-363. doi:10.1038/43854.

Sardenne, F., Bodin, N., Chassot, E., Amiel, A., Fouché, E., Degroote, M., Hollanda, S., Pethybridge, H., Lebreton, B., Guillou, G., and Ménard, F. (2016). Trophic niches of sympatric tropical tuna in the Western Indian Ocean inferred by stable isotopes and neutral fatty acids. Prog. Oceanogr. 146, 7588. doi:10.1016/j.pocean.2016.06.001. 
Sardenne, F., Kraffe, E., Amiel, A., Fouché, E., Debrauwer, L., Ménard, F., and Bodin, N. (2017). Biological and environmental influence on tissue fatty acid compositions in wild tropical tunas. Comp. Biochem. Physiol. Part A Mol. Integr. Physiol. 204, 17-27. doi:10.1016/j.cbpa.2016.11.007.

Schaefer, K. M. (2001). "Reproductive biology of tunas," in Tuna: Physiology, Ecology and Evolution., eds. B. A. Block and E. Stevens (San Diego, California: Academic Press), 225-270. doi:10.1016/S1546-5098(01)19007-2.

Schaefer, K. M., Fuller, D. W., and Block, B. A. (2009). "Vertical Movements and Habitat Utilization of Skipjack (Katsuwonus pelamis), Yellowfin (Thunnus albacares), and Bigeye (Thunnus obesus) Tunas in the Equatorial Eastern Pacific Ocean, Ascertained Through Archival Tag Data," in Tagging and Tracking of Marine Animals with Electronic Devices. Reviews: Methods and Technologies in Fish Biology and Fisheries. vol 9., ed. S. J. Nielsen J.L., Arrizabalaga H., Fragoso N., Hobday A., Lutcavage M. (Springer, Dordrecht), 121-144. doi:10.1007/978-1-4020-9640-2_8.

Schott, F. A., Xie, S.-P., and McCreary, J. P. (2009). Indian Ocean circulation and climate variability. Rev. Geophys. 47, RG1002. doi:10.1029/2007RG000245.

Schott, F., and McCreary, J. (2001). The monsoon circulation of the Indian Ocean. Prog. Oceanogr. 51, 1123. doi:10.1016/S0079-6611(01)00083-0.

Sharp, G. D. (2001). "Tuna Oceanography-an applied science," in Tuna: Physiology, Ecology, and Evolution, eds. B. Block and G. Stevens (San Diego, California: Academic Press), 345-388.

Sharp, G. D., and Dizon, A. E. (1978). The physiological ecology of tunas. Academic Press, London. doi:10.1016/B978-0-12-639180-0.X5001-0.

Shih, C. L., Hsu, C. C., and Chen, C. Y. (2014). First attempt to age yellowfin tuna, Thunnus albacares, in the Indian Ocean, based on sectioned otoliths. Fish. Res. 149, 19-23. doi:10.1016/j.fishres.2013.09.009.

Shuford, R. L., Dean, J. M., Stéquert, B., and M., L. (2007). Elemental fingerprints in otoliths of juvenile yellowfin tuna from spawning grounds in the Atlantic Ocean. Collect. Vol. Sci. Pap. ICCAT 60, 314329.

Shung, S. H. (1973). The sexual activity of yellowfin tuna caught by the longline fishery in the Indian Ocean based on the examination of ovaries. Bull. / Far Seas Fish. Res. Lab. 9, 123-142.

Smale, M. J. (1986). The feeding habits of six pelagic and predatory teleosts in eastern Cape coastal waters (South Africa). J. Zool. 1, 357-409.

Smith, A., Dixon, P., and Black, M. (1988). Population structure of yellowfin tuna (Thunnus albacares) in Eastern Australian waters. University of New SouthWales, Centre for Marine Science Technical Report.

Solovieff, B. S. (1970). Distribution and biology of bigeye tuna in the Indian Ocean. Rybn. Khoz. 3, 313.

Song, L. M., Zhang, Y., Xu, L. X., Jiang, W. X., and Wang, J. (2008). Environmental preferences of longlining for yellowfin tuna (Thunnus albacares) in the tropical high seas of the Indian Ocean. Fish. Oceanogr. 17, 239-253. doi:10.1111/j.1365-2419.2008.00476.x.

Song, L., Zhou, J., Zhou, Y., Nishida, T., Jiang, W., and Wang, J. (2009). Environmental preferences of bigeye tuna, Thunnus obesus, in the Indian Ocean: an application to a longline fishery. Environ. Biol. Fishes 85, 153-171. doi:10.1007/s10641-009-9474-7.

SPC FAME (2019). Impact of climate change on tropical tuna species and tuna fisheries in Pacific Island waters and high seas areas. Informal Paper 3. $11^{\text {th }}$ Heads of Fisheries Meeting, 11-15 March 2019, Noumea, New Caldeonia. Noumea, New Caledonia: Pacific Community. 7 p.

Stephenson, R. L. (1999). Stock complexity in fisheries management: a perspective of emerging issues related to population sub-units. Fish. Res. 43, 247-249. doi:10.1016/S0165-7836(99)00076-4.

Stepien, C. (1995). Population genetic divergence and geographic patterns from DNA sequences: examples from marine and freshwater fishes. in American Fisheries Society Symposium.

Stéquert, B. (1976). Etude de la maturité sexuelle, de la ponte et de la fécondité du listao (Katsuwonus pelamis) de la côte nord-ouest de Madagascar. Cah. ORSTOM. Série Océanographie 14, 227-247.

Stéquert, B., and Marsac, F. (1989). Tropical tuna-surface fisheries in the Indian Ocean. FAO Fish. Tech. 
Stéquert, B., Panfili, J., and Dean, J. (1996). Age and growth of yellowfin tuna, Thunnus albacares, from the western Indian Ocean, based on otolith microstructure. Oceanogr. Lit. Rev. 43. Available at: https://www.infona.pl/resource/bwmeta1.element.elsevier-e89d3c4c-9e2d-3280-b1874d6b2cc9f834 [Accessed June 27, 2016].

Stéquert, B., and Ramcharrun, B. (1995). La fécondité du listao (Katsuwonus pelamis) de l'ouest de l'océan Indien. Aquat. Living Resour. 8, 79-89.

Stéquert, B., Rodriguez, J., and Cuisset, B. (2001). Gonadosomatic index and seasonal variations of plasma sex steroids in skipjack tuna (Katsuwonus pelamis) and yellowfin tuna (Thunnus albacares) from the. Aquat. Living Resour. 14, 313-318. doi:10.1016/S0990-7440(01)01126-3.

Stobberup, K. A., Marsac, F., and Anganuzzi, A. A. (1998). A review of the biology of bigeye tuna, Thunnus obesus, and fisheries for this species in the Indian Ocean. in Proceedings od the first world meeting on bigeye tuna, eds. R. B. Deriso, W. H. Bayliff, and N. J. Webb (La Jolla, California: InterAmerican Tropical Tuna Commission), 81-128.

Tanabe, T., Kayama, S., and Ogura, M. (2003). Precise age determination of young to adult skipjack tuna (Katsuwonus pelamis) with validation of otolith daily increment. Fish. Sci 69, 731-737.

Tanner, S., Reis-Santos, P., and Cabral, H. (2016). Otolith chemistry in stock delineation: A brief overview, current challenges and future prospects. Fish. Res. 173, 206-213. doi:10.1016/j.fishres.2015.07.019.

Temple, A. J., Kiszka, J. J., Stead, S. M., Wambiji, N., Brito, A., Poonian, C. N. S., Amir, O. A., Jiddawi, N., Fennessy, S. T., Pérez-Jorge, S., and Berggren, P. (2018). Marine megafauna interactions with small-scale fisheries in the southwestern Indian Ocean: a review of status and challenges for research and management. Rev. Fish Biol. Fish. 28, 89-115. doi:10.1007/s11160-017-9494-x.

Trueman, C. N., and MacKenzie, K. (2012). Identifying migrations in marine fishes through stable-isotope analysis. J. Fish Biol. 81, 826-847. doi:10.1111/j.1095-8649.2012.03361.x.

van Denderen, P. D., Lindegren, M., MacKenzie, B. R., Watson, R. A., and Andersen, K. H. (2018). Global patterns in marine predatory fish. Nat. Ecol. Evol. 2, 65-70. doi:10.1038/s41559-017-0388-z.

van der Elst, R., Everett, B., Jiddawi, N., Mwatha, G., Afonso, P. S., and Boulle, D. (2005). Fish, fishers and fisheries of the Western Indian Ocean: their diversity and status. A preliminary assessment. Philos. Trans. R. Soc. A Math. Phys. Eng. Sci. 363, 263-284. doi:10.1098/rsta.2004.1492.

Walmsley, S., Purvis, J., and Ninnes, C. (2006). The role of small-scale fisheries management in the poverty reduction strategies in the Western Indian Ocean region. Ocean Coast. Manag. 49, 812-833. doi:10.1016/j.ocecoaman.2006.08.006.

Ward, R., Elliott, N., Innes, B., Smolenski, A., and Grewe, P. M. (1997). Global population structure of yellowfin tuna, Thunnus albacares, inferred from allozyme and mitochondrial DNA variation. Fish. Bull. 95, 566-575. Available at: https://www.infona.pl/resource/bwmeta1.element.elsevier2a4202ad-d95c-3c6b-b4b1-f073b7e91d1a [Accessed August 17, 2018].

Welch, D., Newman, S., Buckworth, R., and Ovenden, J. (2015). Integrating different approaches in the definition of biological stocks: A northern Australian multi-jurisdictional fisheries example using grey mackerel, Scomberomorus semifasciatus. Mar. Policy 55, 73-80. doi:10.1016/j.marpol.2015.01.010.

Wells, R. D., Rooker, J. R., and Itano, D. G. (2012). Nursery origin of yellowfin tuna in the Hawaiian Islands. Mar. Ecol. Prog. Ser. 461, 87-196. doi:10.3354/meps09833.

Wexler, J. B., Margulies, D., and Scholey, V. P. (2011). Temperature and dissolved oxygen requirements for survival of yellowfin tuna, Thunnus albacares, larvae. J. Exp. Mar. Bio. Ecol. 404, 63-72. doi:10.1016/j.jembe.2011.05.002.

Wiggert, J., Murtugudde, R., and Christian, J. (2006). Annual ecosystem variability in the tropical Indian Ocean: Results of a coupled bio-physical ocean general circulation model. Deep Sea Res. Part II Top. Stud. Oceanogr. 53, 644-676. doi:10.1016/j.dsr2.2006.01.027.

Worm, B., and Tittensor, D. (2011). Range contraction in large pelagic predators. PNAS 108, 11942-11947. doi:10.1073/pnas.1102353108.

Wu, G., Chiang, H., Chou, Y., Wong, Z., Hsu, C., Chen, Y., and Yang, H. (2010). Phylogeography of 
yellowfin tuna (Thunnus albacares) in the Western Pacific and the Western Indian Oceans inferred from mitochondrial DNA. Fish. Res. 105, 248-253. doi:10.1016/j.fishres.2010.03.015.

Wujdi, A., Setyadji, B., and Nugroho, S. C. (2017). Preliminary stock structure study of Skipjack tuna (Katsuwonus pelamis) from south java using otolith shape analysis. IOTC-2017-WPTT19-42.

Yano, K. (1991). An interim analysis of the data on tuna tagging collected by R/V Nippon Karu in the Indian Ocean, 1980-1990. in Southeast Asian Tuna Conference (Bangkok, Thailand).

Ye, Z. J., Wang, Y. J., and Gao, T. X. (2003). Study on tuna longline fishery in the Eastern Indian Ocean: The Biology of Thunnus obesus Captured. Ocean Univ. Qingdao 33, 343-348.

Ying, Y., Chen, Y., Lin, L., and Gao, T. (2011). Risks of ignoring fish population spatial structure in fisheries management. Can. J. Fish. Aquat. Sci. 68, 2101-2120. doi:10.1139/F2011-116.

Young, J., and Davis, T. (1990). Feeding ecology of larvae of southern bluefin, albacore and skipjack tunas (Pisces: Scombridae) in the eastern Indian Ocean. Mar. Ecol. Prog. Ser. 61, 17-29. Available at: http://www.jstor.org/stable/24842244.

Zhu, G. P., Dai, X. J., Song, L. M., and Xu, L. X. (2011). Size at Sexual Maturity of Bigeye Tuna Thunnus obesus (Perciformes: scombridae) in the Tropical Waters: a Comparative Analysis. Turkish J. Fish. Aquat. Sci. 11, 149-156. doi:10.4194/trjfas.2011.0119.

Zhu, G., Xu, L., Zhou, Y., and Song, L. (2008). Reproductive Biology of Yellowfin Tuna T. albacares in the West-Central Indian Ocean. J. Ocean Univ. China 7, 327-332. doi:10.1007/s11802-008-0327-3.

Zudaire, I., Chassot, E., Murua, H., Dhurmeea, Z., Cedras, M., and Bodin, N. (2016). Sex-ratio, size at maturity, spawning period and fecundity of bigeye tuna (Thunnus obesus) in the western Indian Ocean. IOTC-2016-WPTT18-37.

Zudaire, I., Murua, H., Grande, M., and Bodin, N. (2013a). Reproductive potential of yellowfin tuna (Thunnus albacares) in the western Indian Ocean. Fish. Bull. 11, 252-264. doi:10. 7755/FB.111.3.4.

Zudaire, I., Murua, H., Grande, M., Goñi, N., and Potier, M. (2015). Variations in the diet and stable isotope ratios during the ovarian development of female yellowfin tuna (Thunnus albacares) in the Western Indian Ocean. Mar. Biol. 162, 2363-2377. doi:10.1007/ s00227-015-2763-0.

Zudaire, I., Murua, H., Grande, M., and Korta, M. (2013b). Fecundity regulation strategy of the yellowfin tuna (Thunnus albacares) in the Western Indian Ocean. Fish. Res. 138, 80-88. doi:10.1016/j.fishres.2012.07.022.

Zudaire, I., Murua, H., Grande, M., Pernet, F., and Bodin, N. (2014). Accumulation and mobilization of lipids in relation to reproduction of yellowfin tuna (Thunnus albacares) in the Western Indian Ocean. Fish. Res. 160, 50-59. doi:10.1016/j.fishres.2013.12.010. 


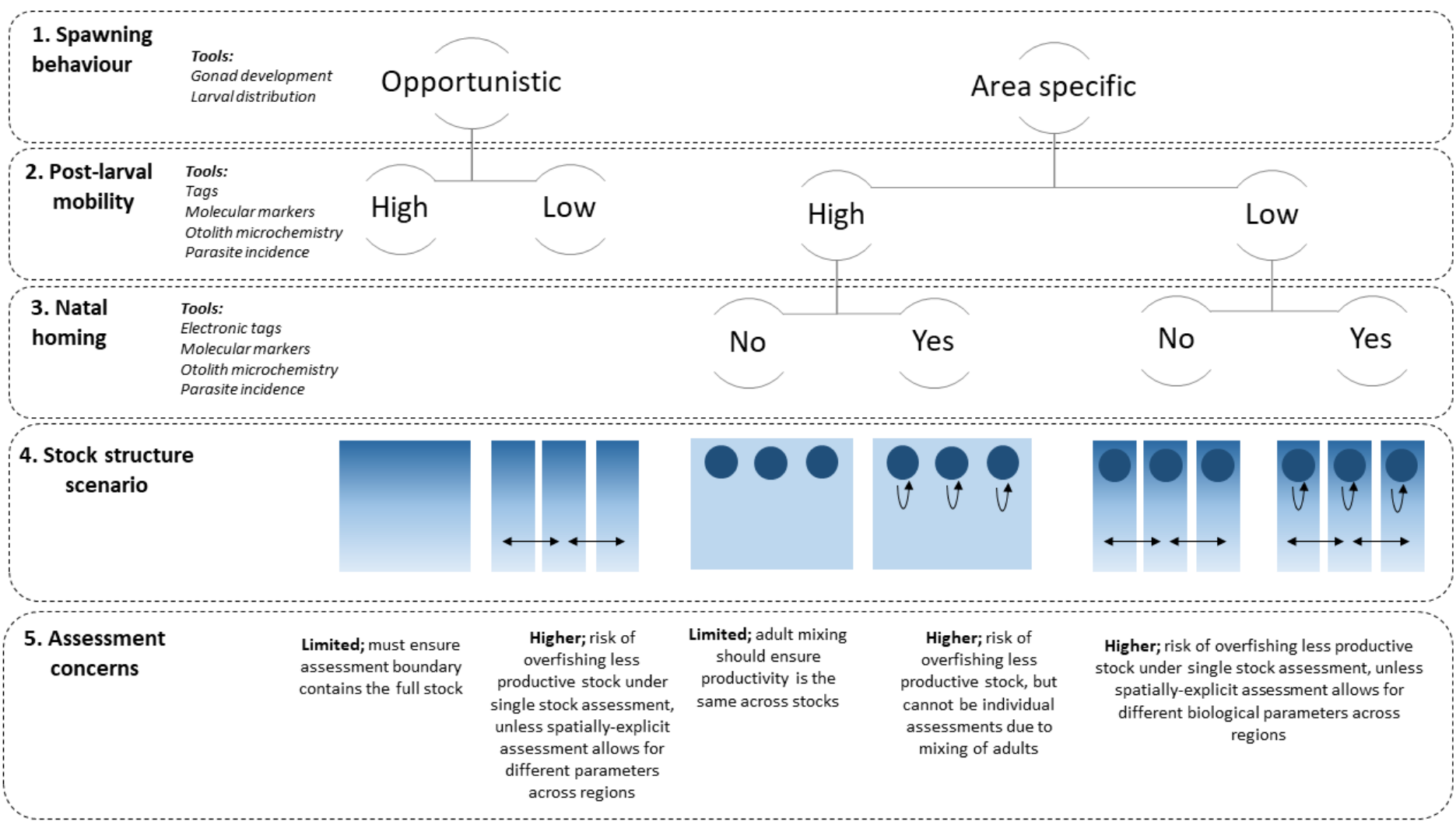

1332

1333 Figure 1. Conceptual summary of key research themes necessary to clarify the stock structure of tropical 1334 tuna species in the Indian Ocean; (1) spawning conditions (opportunistic vs. discrete), (2) post-larval 1335 mobility (low vs high) and (3) natal homing (yes vs no). Different combinations lead to different scenarios 1336 of stock structures (4), associated with potential stock assessment concerns (5). Stock structure diagrams 1337 indicate spawning areas (dark blue) within the overall distribution range (ligth blue) of the species. Main 1338 tools to study each research theme are also indicated. This figure is an adaptation from (SPC FAME, 2019). 

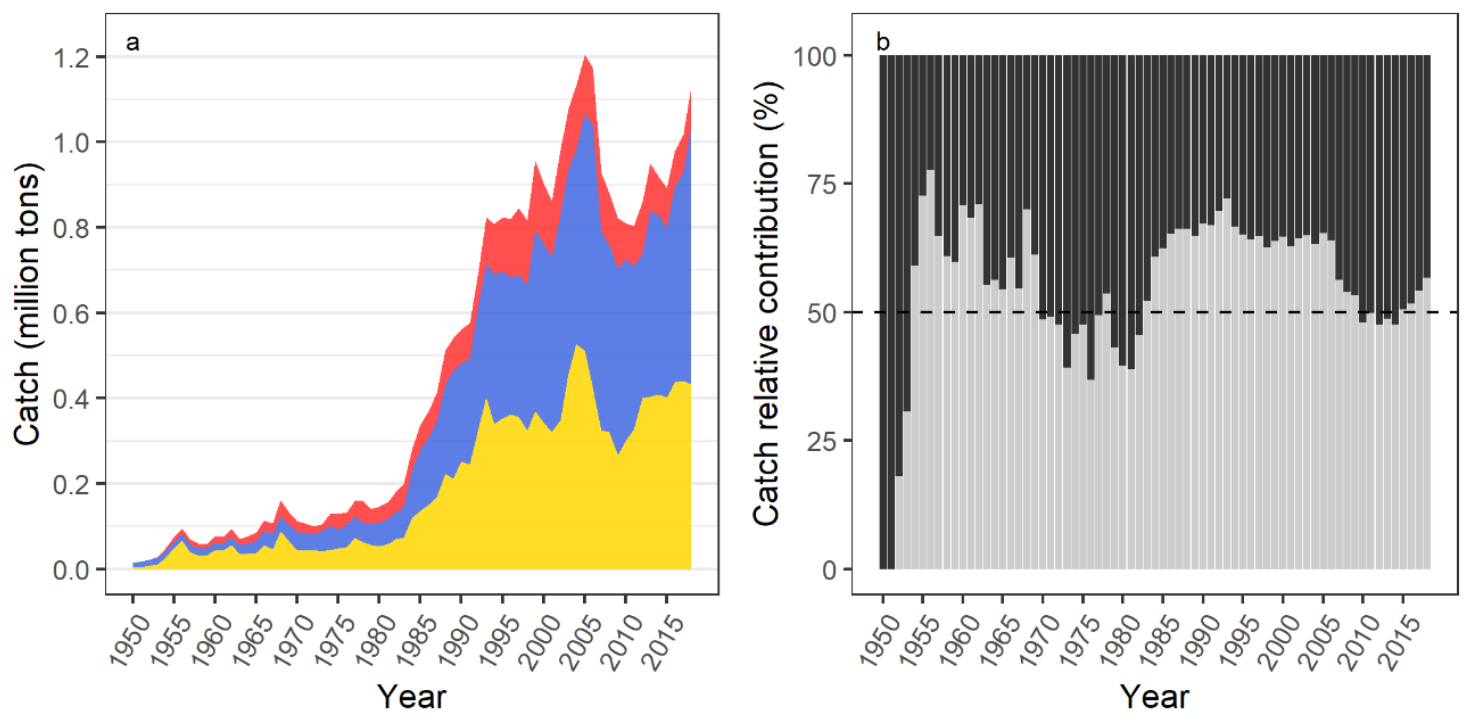

Figure2. Evolution of tropical tuna catches in the Indian Ocean over the 1950-2018 period; (a) Catch trends of, bigeye Thunnus obesus (red), skipjack Katsuwonus pelamis (blue) and yellowfin Thunnus albacares (yellow) in the Indian Ocean, (b) Relative contribution (\% of total catches for each year) from the artisanal (light grey) vs industrial fisheries (dark grey). Data source: Indian Ocean Tuna Comission (IOTC) (avaible at: https://www.iotc.org/data/datasets/latest/NC). 

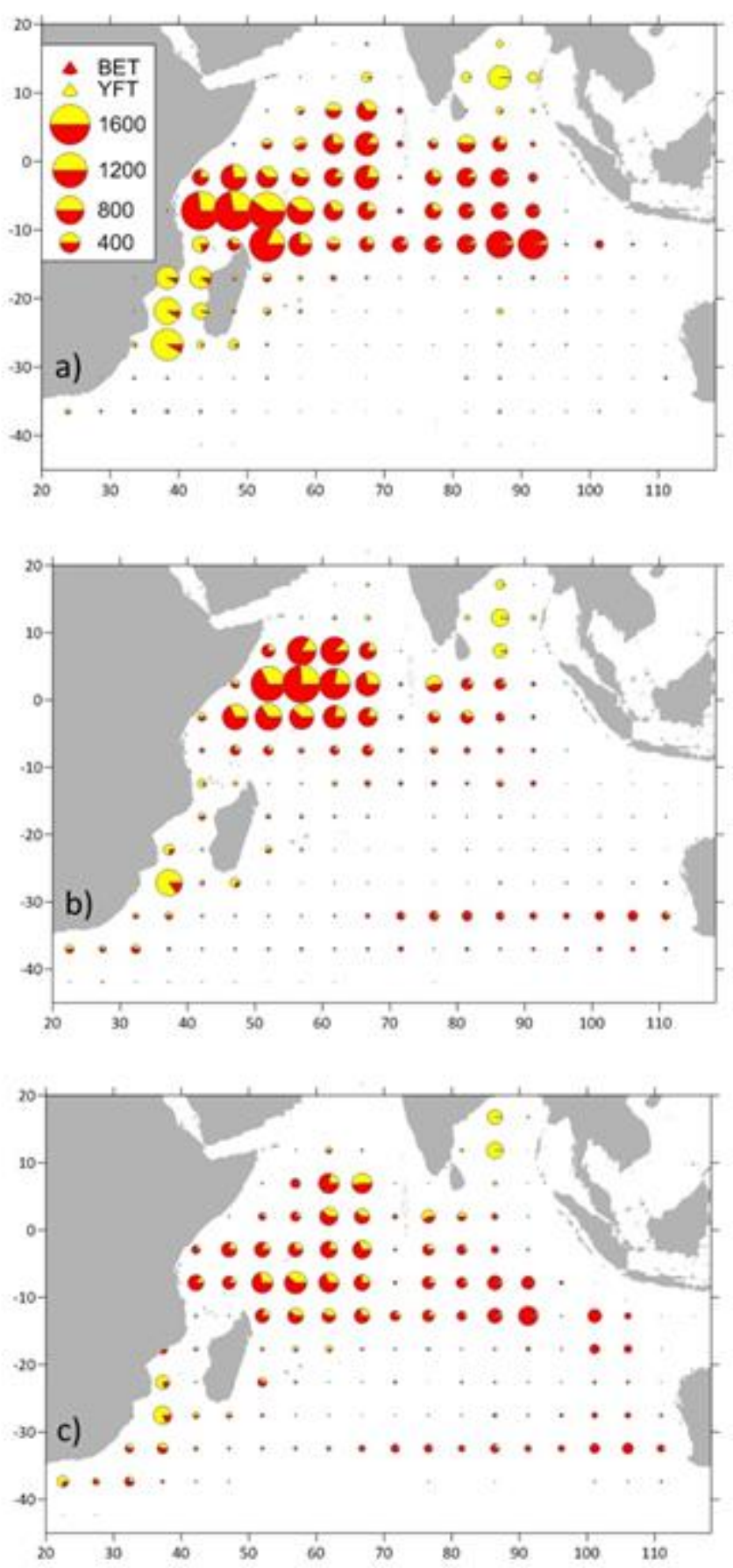

Figure 3. Average spatial distribution of longline catches over 2010-2017 for the months NovemberFebruary (a), March-June (b) and July-October (c). Circles are plotted on a $5^{\circ} \times 5^{\circ}$ grid and pies are proportional to the catch by species (yellow: yellowfin; red: bigeye). The spatialized data originate from the Indian Ocean Tuna Comission, IOTC (avaiable at: http://www.iotc.org/documents/all-ce-files) but as they are incomplete, they have been raised to the nominal catches by applying raising factors established by fleet, year and species. A few data were available by $1^{\circ} \times 1^{\circ}$ and they have been aggregated on a $5^{\circ} \times 5^{\circ}$

1356 grid to enhance visibility. 

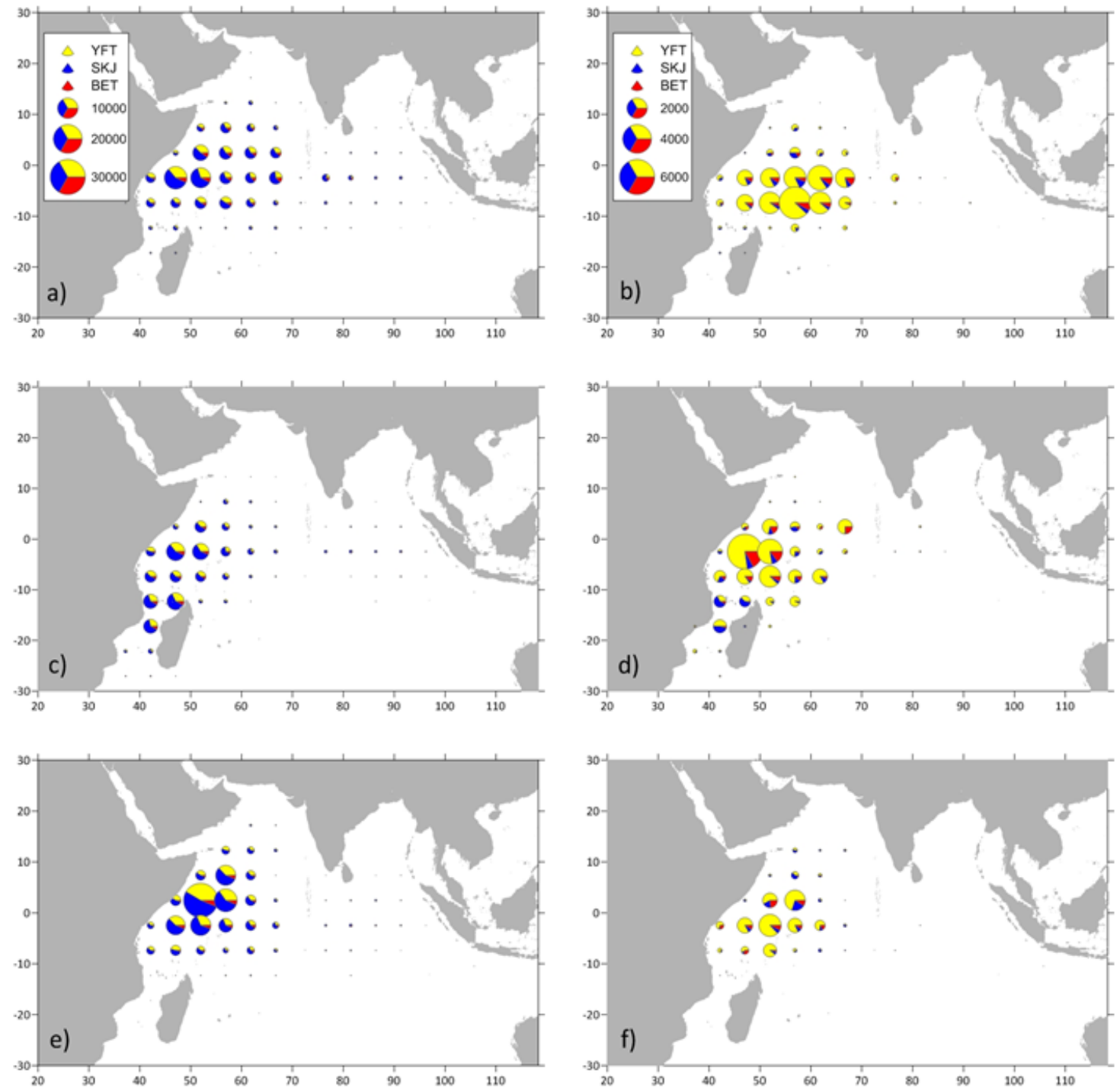

Figure 4. Average spatial distribution of purse seine catches over 2010-2017 for the months NovemberFebruary (a,b), March-June (c,d) and July-October (e,f). Left column (a,c,e) show catches on floating objects, while right column $(\mathrm{b}, \mathrm{d}, \mathrm{f})$ represent catches on free-swimming schools. Circles are plotted on a $5^{\circ} \times 5^{\circ}$ grid and pies are proportional to the catch by species (yellow: yellowfin; blue: skipjack; red: bigeye). Note the different scales and maximum between floating objects and free-swimming schools. The spatialized data originate the Indian Ocean Tuna Comission, IOTC (avaiable at: http://www.iotc.org/documents/all-ce-files) but as they are incomplete, they have been raised to the nominal catches by applying raising factors established by fleet, year and species. Purse seine data are mostly available by $1^{\circ} \times 1^{\circ}$ and they have been aggregated on a $5^{\circ} \times 5^{\circ}$ grid to enhance visibility. 


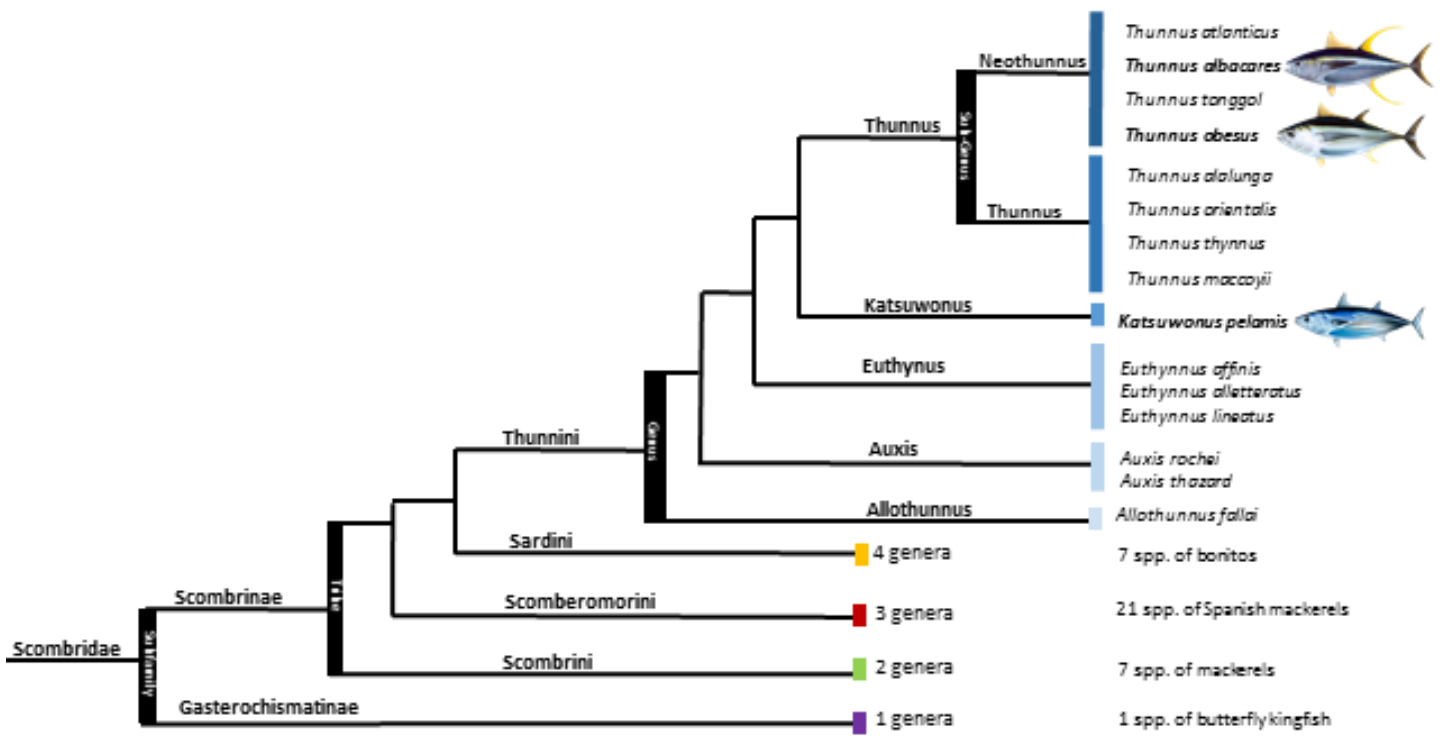

1369

1370 Figure 5. Phylogenetic tree of the Scombridae family, which consists of 15 genera and 51 species, among which the three main species of tropical tuna, yellowfin (Thunnus albacares), bigeye (Thunnus obesus) and 1372 skipjack tuna (Katsuwonus pemalis) are found (Collette et al., 2001). The sub-genus branch is based on 1373 findings from Díaz-Arce et al. (2016). 


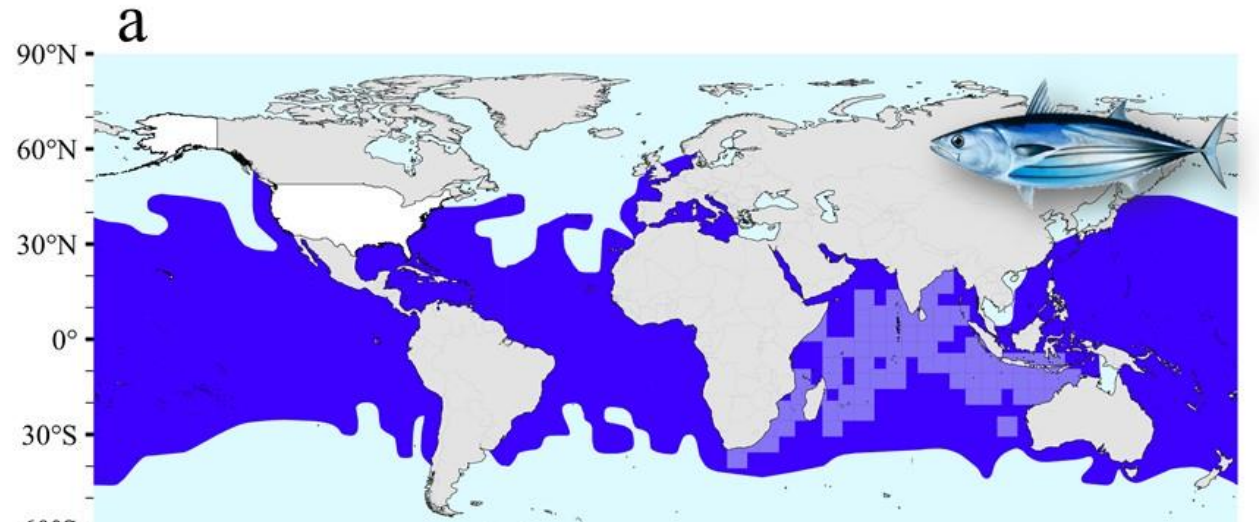

$60^{\circ} \mathrm{S}$

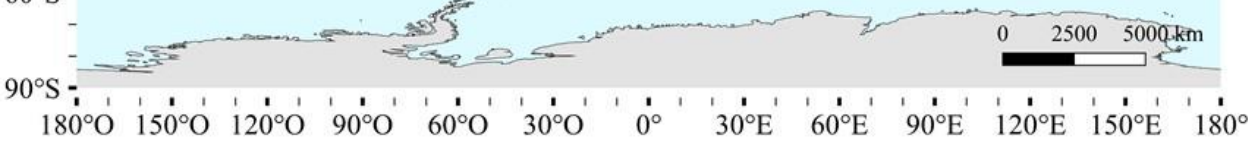

b

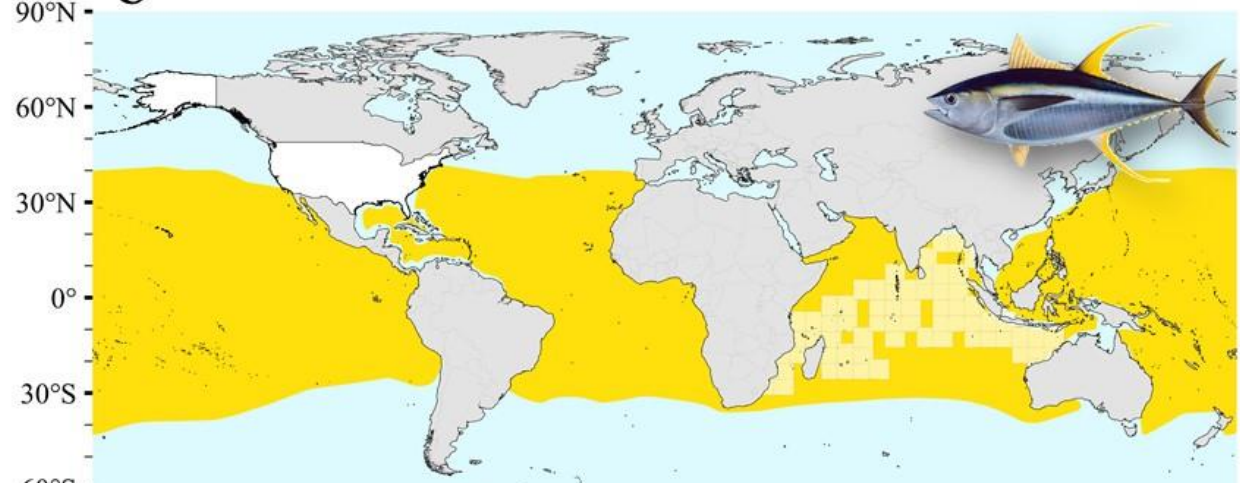

$60^{\circ} \mathrm{S}-$

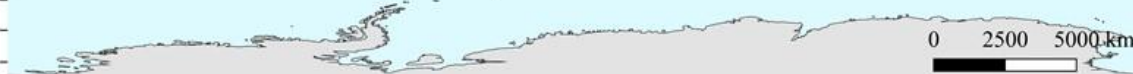

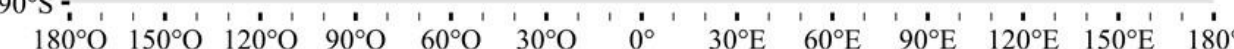

$\mathrm{C}$

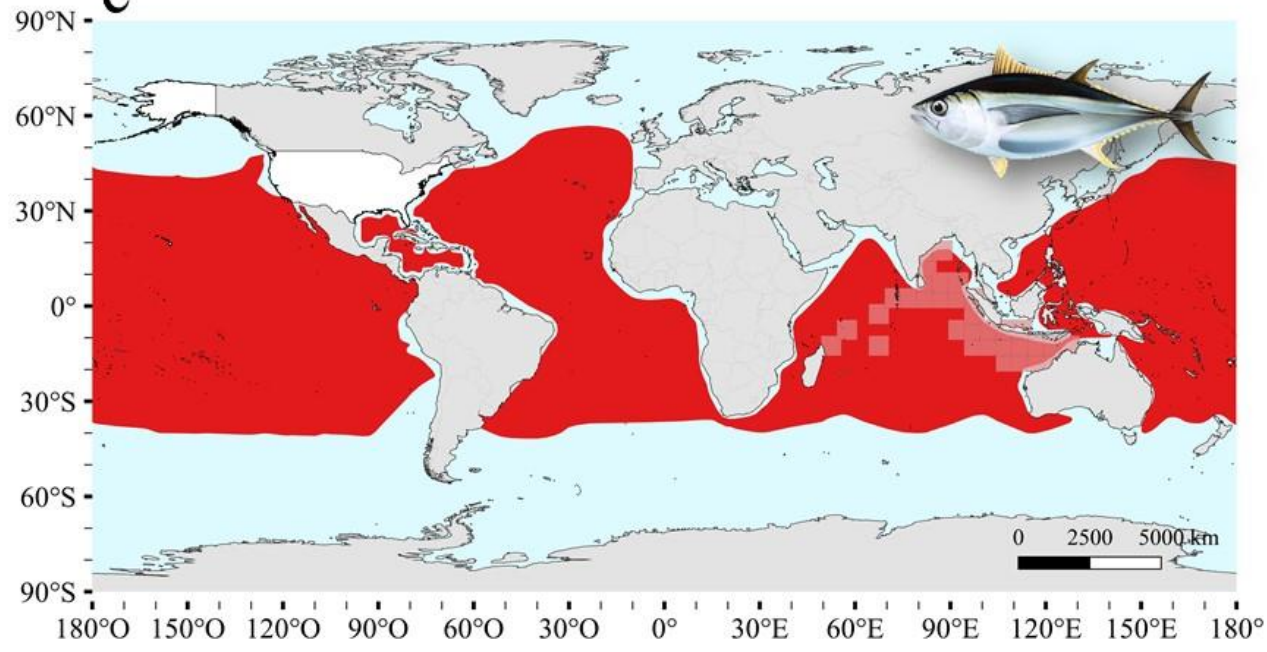

1376 Figure 6. Potential habitat distribution range of (a) skipjack tuna Katsuwonus pelamis, (b) yellowfin tuna, 1377 Thunnus albacares, and (c) bigeye tuna, Thunnus obesus. Lighter squares represent the presence of larvae 1378 (based on Reglero et al. 2014). Distribution range was obtained from the IUCN Red List Spatial Data of 1379 tunas and billfishes version 5.2 (available at: https://www.iucnredlist.org/resources/spatial-data-download 1380 ). Tuna images: IOTC (C) 2020. 


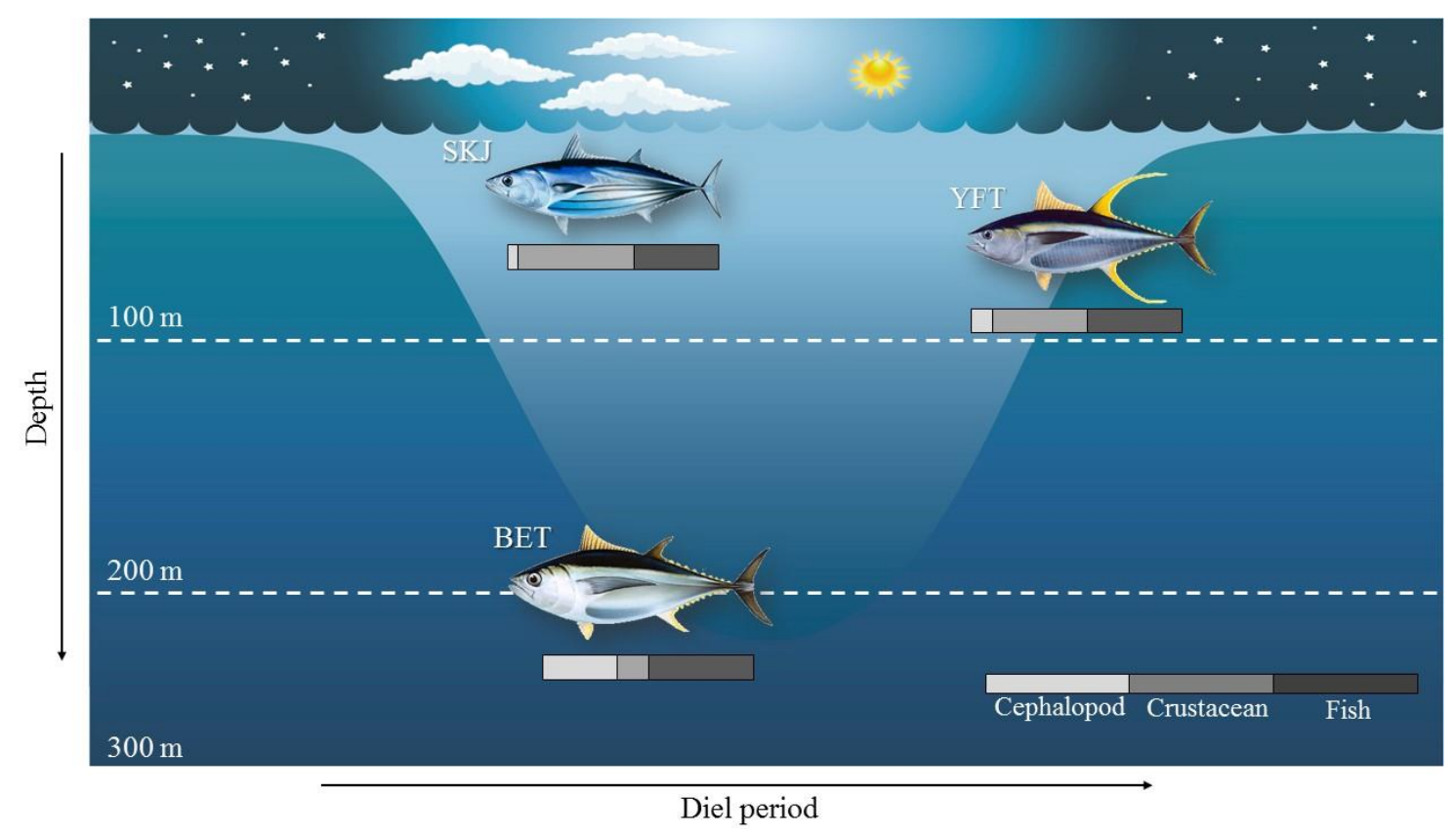

1382 Figure 7. Trophic niche partitioning of adult tropical tuna in the western Indian Ocean: SKJ, skipjack tuna, Katsuwonus pelamis; YFT, yellowfin tuna, Thunnus albacares; BET, bigeye tuna, Thunnus obesus. Bars represent the importance of the main prey categories, squid (light grey), crustacean (mid grey) or fish (dark grey), in the diet of each predator (percent of the reconstituted weight). Adapted from Olson et al. (2016). Tuna images: IOTC (C) 2020. 

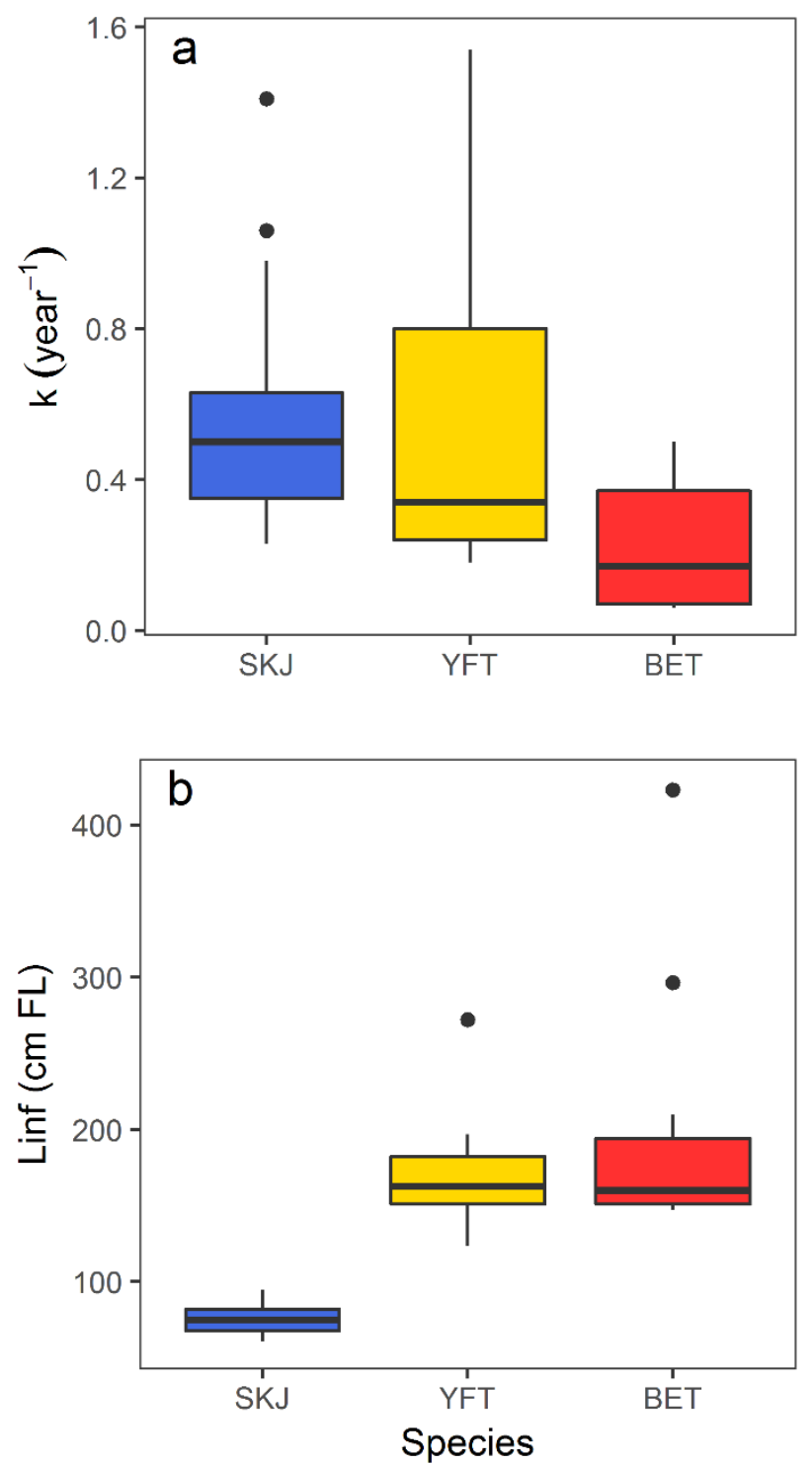

1402

1403 Figure 8. Comparison of reported growth rate coefficients $(\mathrm{k})$ and asymptotic fork lengths $\left(\mathrm{L}_{\infty}\right)$ for skipjack (blue), yellowfin (yellow) and bigeye (red) tuna in the Indian Ocean. Growth parameters have been obtained 1405 from Murua et al., 2017 supplementary material tables 10S, 13S and 16S.

1406 

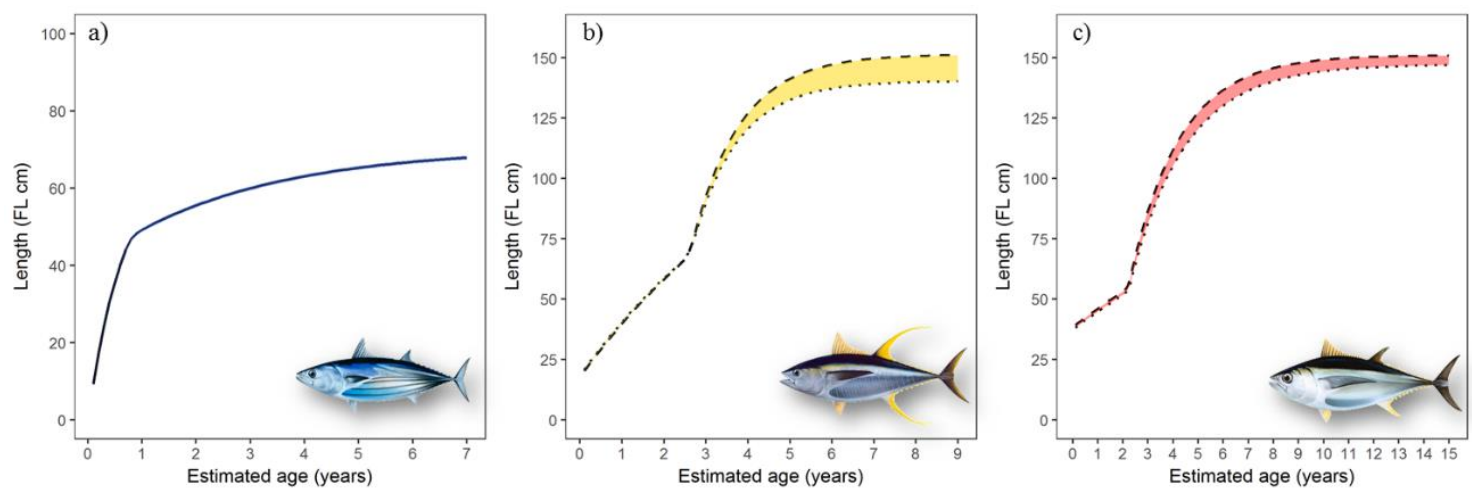

1407

1408

1409

1410

1411

1412
Figure 9. VB $\log \mathrm{K}$ growth curves for (a) skipjack Katsuwonus pelamis, (b) yellowfin, Thunnus albacares, and (c) bigeye tuna, Thunnus obesus in the Indian Ocean after following (Eveson et al., 2015). In the case of yellowfin and bigeye tuna, growth is sex-specific, represented with a longdashed lines in males and with dotted lines in females. Tuna images: IOTC @ 2020. 

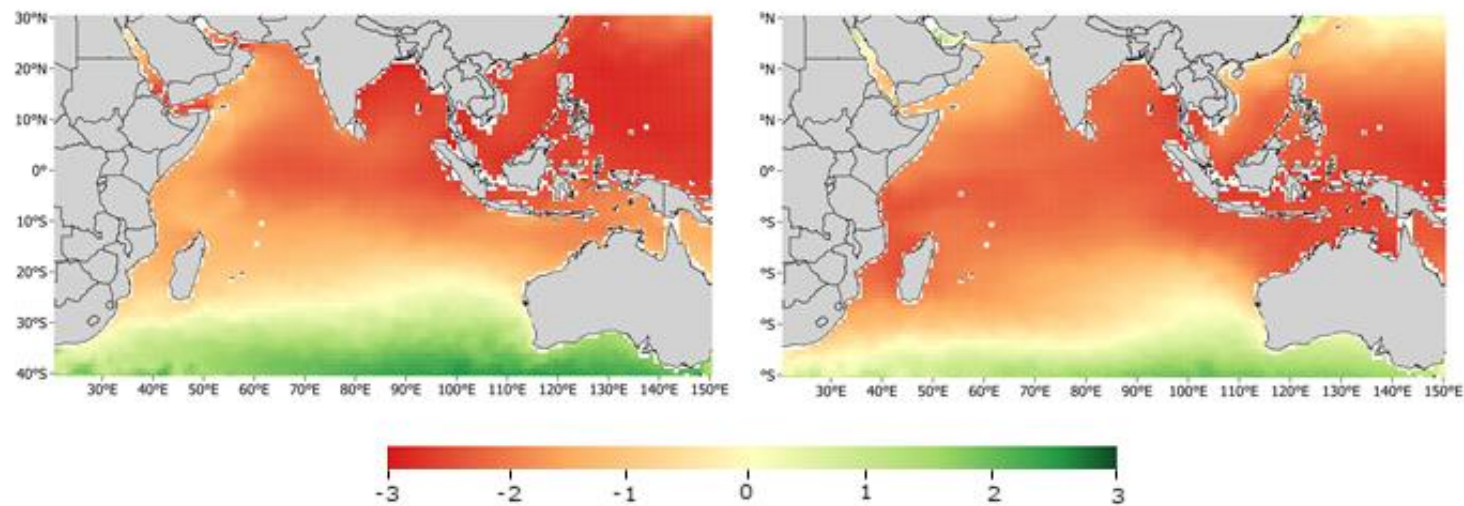

1414 Figure 10. Predicted spatial variations in isotopic composition of oxygen in otoliths $\left(\delta^{18} \mathrm{O}_{\text {oto }}\right)$ following 1415 Trueman and MacKenzie (2012) and based on global surface water $(0-50 \mathrm{~m})$ measured $\delta^{18} \mathrm{O}_{\mathrm{w}}$ values 1416 (LeGrande and Schmidt, 2006), and parameters $\gamma$ and $\beta$ from Kitagawa et al., (2013). Maps are differentiated for summer monsoon (Jun-Sept 2017) and winter monsoon (Dec-Apr 2016-2017). Monthly data of Sea Surface Temperature (SST, ${ }^{\circ} \mathrm{C}$ ) was obtained from the "global-reanalysis-phy-001-031-grepv2montlhy" dataset available in the EU Copernicus Marine Service Information (avaible at: 1420 https://marine.copernicus.eu/). Note that this simplistic model assumes constant parameters for the otolith fractionation equation and is based on coupled measurements of $\delta^{18} \mathrm{O}_{\mathrm{w}}$ values and SST at a spatial resolution of $1 \times 1^{\circ}$ grid. 
Table 1. Summary of studies on Indian Ocean tropical tuna spawning seasonality. SKJ; skipjack tuna, Katsuwonus pelamis, YFT; yellowfin tuna, Thunnus albacares, and BET; bigeye tuna, Thunnus obesus. When two spawning seasons have been described in the same study 1; Main spawning season and 2; Secondary spawning season.

\begin{tabular}{|c|c|c|c|}
\hline & Region & Spawning season & Source \\
\hline SKJ & Western Indian Ocean & $\begin{array}{l}\text { Year- round, but peaks of } \\
\text { activity between November- } \\
\text { March and June-July }\end{array}$ & (Stéquert et al. 2001) \\
\hline SKJ & Western Indian Ocean & $\begin{array}{l}\text { Year-round, but peaks of } \\
\text { activity between November- } \\
\text { March and June-July }\end{array}$ & (Grande et al. 2014) \\
\hline SKJ & Indian waters & $\begin{array}{l}\text { Year-round, peak of activity } \\
\text { between December-March and } \\
\text { a minor one from June to } \\
\text { August }\end{array}$ & (Koya et al. 2012) \\
\hline YFT & $\begin{array}{l}\text { Central Indian Ocean, south } \\
\text { Seychelles, west Sumatra }\end{array}$ & $\begin{array}{l}\text { January to March } \\
\text { 1: January to March, 2: April to }\end{array}$ & $\begin{array}{l}\text { (Stéquert and Marsac } \\
\text { 1989) }\end{array}$ \\
\hline & Sri Lanka & June & \\
\hline & $\begin{array}{l}\text { North Madagascar, north } \\
\text { Australia }\end{array}$ & 2: October to December & \\
\hline YFT & Western Indian Ocean & November to April & $\begin{array}{l}\text { (Hassani and Stéquert } \\
\text { 1991) }\end{array}$ \\
\hline YFT & Seychelles EEZ & November to February & (Majid and Ahmed 1991) \\
\hline YFT & Pooled data for the Indian EEZ & January to April/May & (John and Sudarsan 1993) \\
\hline YFT & Andaman Sea & November to April & (John 1995) \\
\hline YFT & Bay of Bengal & November to April & (John et al. 1998) \\
\hline
\end{tabular}


YFT North Arabian Sea

YFT Western Indian Ocean

YFT Eastern Indian Ocean

YFT West Central Indian Ocean

YFT Western Indian Ocean

BET Indian Ocean

BET Eastern Indian Ocean

BET Southern Central Indian Ocean

BET Indian Ocean

Eastern Indian Ocean

BET Western Indian Ocean
December to June

(Govindraj et al. 2000)

1: November to March, 2: June （Stéquert et al. 2001)

to August

November to April

(Nootmorn et al. 2005)

January to June

(Zhu et al. 2008)

1: November to February, 2: (Zudaire et al. 2013)

June

December to March

(IOTC 2017a)

January to March

(Solovieff 1970)

October to January

(Ye et al. 2003)

October to January

(Li et al. 2010)

1: December to January

(IOTC 2017b)

2: June

January to March

(Zudaire et al. 2016)

1428

1429 